\title{
Sea-level change and shore-line evolution in Aegean Greece since Upper Palaeolithic time
}

\author{
KURT LAMBECK *
}

'As the glaciation ended, the ice melted and the sea-level rose.' Yes - but it has not been as simple as that, as the Earth has adjusted in several ways to the changing surface-loads it suffers under ice and under weight of water. The important issues are set out in a simple mathematical treatment, and their varied consequences are shown for Greece and especially for the Greek coastal plains and the Greek islands, where the impact on human settlement has been large.

\begin{abstract}
Nature and consequences of Postglacial sealevel change

Sea-levels have changed significantly since Late Palaeolithic time, primarily in response to the melting of the great ice-sheets that covered northern Europe and North America. These icesheets were of a sufficiently large volume that, upon melting, sea-level rose globally by about $120-130 \mathrm{~m}$. Release of this ice into the oceans was initiated at about 18,000 years before present (b.p.), although the majority of the melting occurred between about 16,000 and 8000 b.p. ${ }^{1}$ Rates of global sea-level rise reached 15-20 mm per year during this interval. As the sea-levels rose, so did the shorelines migrate with time, at rates that for some low-lying regions reached about a kilometre per year. Examples of where such rapid encroachment of the sea occurred include the Persian Gulf and the Gulf of Carpentaria of northern Australia, between about 12,000 and 10,000 years b.p. In some areas of the world the sea-levels peaked at about 6000 years b.p., inundating now low-lying areas before falling slowly to their present position. The consequences of these changes on human settlement and movement have been recognized in the archaeological and pre-historic records. Thus it is widely accepted that levels during
\end{abstract}

1 All ages are in conventional radiocarbon years unless otherwise specified. the Last Glacial Maximum, about 20,000 to 18,000 years ago, were sufficiently lower than today to leave exposed coastal plains that have since flooded. But less attention appears to have been focused on the timing and rates of change after the onset of melting of the great ice-sheets. What discussion there is - with the exception of the important paper by van Andel \& Shackleton (1982) (see also van Andel 1989) - often leaves the distinct impression that this change in level occurred early and quickly with rather minimal human impact.

This paper sets out to describe, using the Aegean Sea region as an example, a realistic model of sea-level change and shoreline migration for the past 20,000 years, one that can provide a framework for discussing impacts of such change on human movements and settlement.

If, during the decay of the ice sheets, the meltwater volume is distributed uniformly over the oceans, then the sea-level change at time $t$ would be

$\Delta \zeta_{\mathrm{e}}(t)=$ change in ocean volume/ocean surface area (1)

This 'eustatic sea-level change' is a function of time. It represents only a zero-order approximation because sea-level does not respond uniformly to the melting of the ice caps: the rates of rise are spatially variable, and in some localities sea-level may actually be falling rela-

* Research School of Earth Sciences, Australian National University, Canberra ACT 0200, Australia.

Received 23 January 1996, accepted 26 April 1996.

ANTIQUITY 70 (1996): 
tive to the land. This is a consequence of the adjustment of the Earth to the changing surface-loads of ice and meltwater. The Earth's response can be described as that of an elastic layer (the lithosphere which includes the crust) overlying a viscoelastic mantle. When changes in the mass distribution occur on the Earth's surface, the lithosphere and mantle respond to the new stress state in different ways: elastic deformation primarily occurs in the lithosphere and viscous flow occurs primarily in the underlying mantle. The characteristic time-scale of this flow is of the order of a few thousand years. The deformation of the Earth's surface under a changing load therefore exhibits both an instantaneous elastic response and a viscous response. Such behaviour is well documented by other geophysical observations: gravitational attraction of the Sun and Moon raises tides in the solid Earth; ocean tides load the sea floor and contribute to the deformation of the Earth's surface; atmospheric pressure fluctuations over the continents induce deformations in the solid Earth. These displacements, when measured with precision scientific instruments, show both an elastic and a viscous component, with the latter becoming increasingly important as the duration of the load or force increases. Changes in the ice and water loads occurring at times of major deglaciation are much larger and occur on longer time-scales than these small atmospheric and tidal perturbations, but the theory underpinning the formulation of the surface rebound problem is similar and has been tested against a range of different observations (e.g. Lambeck 1988).

When the ice-sheets melt, the surface load is changed in two ways. Ice is removed, thereby unloading the formerly glaciated crust, and the meltwater is added into the oceans, loading the oceanic lithosphere. The resulting change in sea-level relative to the land is a combination of two reactions: the increase in ocean volume, and the deflection of the land surface. Depending on which contribution is greater, sea-level is seen to rise or fall relative to the land. In regions near or within the former centres of glaciation, the crustal adjustment is one of uplift; it is usually the more important, and sea-level here is seen to fall. Further away from the ice sheets, the crustal rebound is small and generally one of subsidence; here the change in ocean volume dominates, and sea-level is seen to rise.
Because of the viscous nature of the planet's interior, the crustal deformation continues long after the melting of the Late Pleistocene icesheets has ceased; and shorelines have continued to change up to the present.

This combined behaviour of the eustatic change and the crustal rebound describes a firstorder solution to the question of what happens to sea-level when ice sheets melt. A more complete description requires consideration of two additional effects:

- the fact that newly added meltwater loads the sea floor and stresses the mantle, resulting in further mantle flow and surface displacement;

- the gravity field of the earth is changing; first, because of the changing gravitational attraction between the ice, water and land as the ice sheets melt, and second, because of the redistribution of mass within the solid Earth in response to the mantle flow and surface deflection.

The total effect of these various processes is called 'glacio-hydro-isostasy' after the (regional) isostatic response of the Earth's surface to the ice and water loads. It leads to a complex spatial and temporal pattern of sea-level change as the ice sheets wax and wane, making the concept of a uniform global eustatic change of only very limited value. This complexity is more than a scientific curiosity, as its understanding has broad scientific impacts. In geophysics, for example, the spatial changes in sea-level provide a valuable insight into physical properties of the Earth that cannot otherwise be measured. In environmental studies they provide a framework for separating natural from man-caused changes in sea-level. In prehistory and archaeology, they provide a basis for detailed geographic reconstructions of coastal regions and for assessing the impact of changing sea-levels on past societies.

\section{Models for sea-level change}

The evaluation of the evolution of shorelines during times of glaciation and deglaciation requires knowledge of several quantities:

- the change in sea-level relative to the land for the region in question, a change that is usually regionally variable;

- the present topography of the low-lying land areas and shallow sea-floor bathymetry for the region; 
- any information on tectonics, sedimentation or erosion that may have changed the geometry of the coastal zone.

Because of the spatial variability of the sea-level change, the best way to establish a record of the past positions at a particular location is to infer it from the geological, geomorphological and archaeological record. But observations that permit a quantitative estimate of the changing position of the sea surface seldom exist for the area of interest and - at best -- it probably consists of a partial time series. Also, such records become increasingly rare and imprecise the further one goes back in time. What is required is a physical model for interpolation between the available fragments of information so as to be able to predict sea-level at any place and time. For tectonically stable regions the glacio-hydro-isostatic theory provides a relatively smoothly varying and predictable function of such change in time and space that can be used to interpolate between isolated observations. But when active vertical tectonic processes are important, resulting in surface faulting or warping, the interpolation model becomes much more difficult because the crustal displacements can change abruptly over comparatively short distances and need not be uniform in time when viewed over periods of the order of millennia.

The approach used here is to develop models of eustasy and glacio-hydro isostasy for tectonically stable areas so that physical parameters describing the Earth response and the ice sheets can be evaluated. The result is a comprehensive portrayal results of global sea-level change in response to the growth and decay of the large ice sheets. When these models are applied to tectonically active areas any departures of observed sea-levels from the modelpredicted values can be attributed to tectonic factors. The success of this approach does depend on whether the isostatic predictions are representative of the region under consideration. If this can be demonstrated, then the model can be used to predict the positions of former shorelines and palaeo-water depths.

\section{The sea-level equation}

In the presence of vertical tectonic motions of the Earth's surface, the relative sea-level change $\Delta \zeta(\varphi, t)$ at a site $\varphi$ and time $t$ can be written schematically as:

$$
\Delta \zeta(\varphi, t)=\Delta \zeta_{e}(t)+\Delta \zeta_{I}(\varphi, t)+\Delta \zeta_{T}(\varphi, t)
$$

where $\Delta \zeta_{e}(t)$ is the previously defined eustatic sea-level $(1), \Delta \zeta_{\Gamma}(\varphi, t)$ is the combined glaciohydro-isostatic contribution, and $\Delta \zeta_{T}(\varphi, t)$ is any additional tectonic contribution. This last contribution is discussed further below and the emphasis here is on the isostatic function, which can be written as the sum of three parts:

$$
\Delta \zeta_{I}(\varphi, t)=\Delta \zeta_{r}(\varphi, t)+\Delta \zeta_{i}(\varphi, t)+\Delta \zeta_{w}(\varphi, t)
$$

The total sea-level change is expressed as:

$\Delta \zeta(\varphi, t)=\Delta \zeta_{e}(t)+\Delta \zeta_{\Gamma}(\varphi, t)+\Delta \zeta_{i}(\varphi, t)+\Delta \zeta_{w}(\varphi, t)+\Delta \zeta_{T}(\varphi, t)$

The eustatic term $\Delta \zeta_{e}(t)$ in $(4)$ is a function of the rate of change in ocean volume and its evaluation requires a knowledge of the rate of melting of the totality of the ice caps. The second term $\Delta \zeta_{\Gamma}(\varphi, t)$ describes the departures of sealevel change from eustasy on a rigid planet by allowing for the change in gravitational attraction between the ice and water as the ice sheets melt, and between the water and land as the ocean volumes increase. During times of icesheet growth, the increasing gravitational attraction of the ice pulls the water towards the expanding ice dome; in the absence of the other contributions, sea-level rises in the neighbourhood of the ice while further away it falls. $\Delta \zeta_{r}$ is therefore a function of the ice sheet geometry through time and of the geometry of the ocean basin from which the water is extracted. This term, most significant in areas close to the ice sheets, remains non-negligible out to considerable distances beyond the ice margins. The attraction by the northern ice is still sufficient in Greece, for example, to 'pull up' the Mediterranean water, and this correction is positive at times of major glaciation (see FIGURE 2a below); sea-levels at these early epochs would have been higher than at the present if the other contributions had been ignored. The major contribution is from the Fennoscandian ice, but contributions from the North American and Antarctic ice sheets are not negligible if sealevel models accurate to a metre or less are sought.

The term $\Delta \zeta_{i}(\varphi, t)$ in (4) describes the consequence on sea-level of the deformation of the Earth under the changing ice load; it includes a contribution from changes in the gravity field associated with the redistribution of mass within 
FIGURE 1. Examples of predicted (solid lines) and observed (with error bars, right-hand side) relative sea-level change in lateand post-glacial times from different localities. The curves on the righthand side illustrate the total predicted change and the observed change at selected sites. The geographical variation in these changes is interpreted as the combination of the eustatic change (indicated by e.s.l. on the left-hand side) and the glacio-hydro-isostatic adjustment of the crust in response to the glacial unloading (indicated by ice for the glacio-term and water for the hydroterm).

a The Angerman River, Sweden: the glacioisostatic rebound dominates over the eustatic change.

b The upper Forth Valley, Scotland: the isostatic and eustatic terms are of comparable magnitude but opposite signs.

$\mathrm{C}$ Southern England: the dominant contribution is the eustatic component but the glacio- and hydroisostatic contributions are also significant.

d Karumba in the Gulf of Carpentaria, Australia, a continental margin site far from the former ice loads: the dominant isostatic perturbation is the hydro-isostatic component.
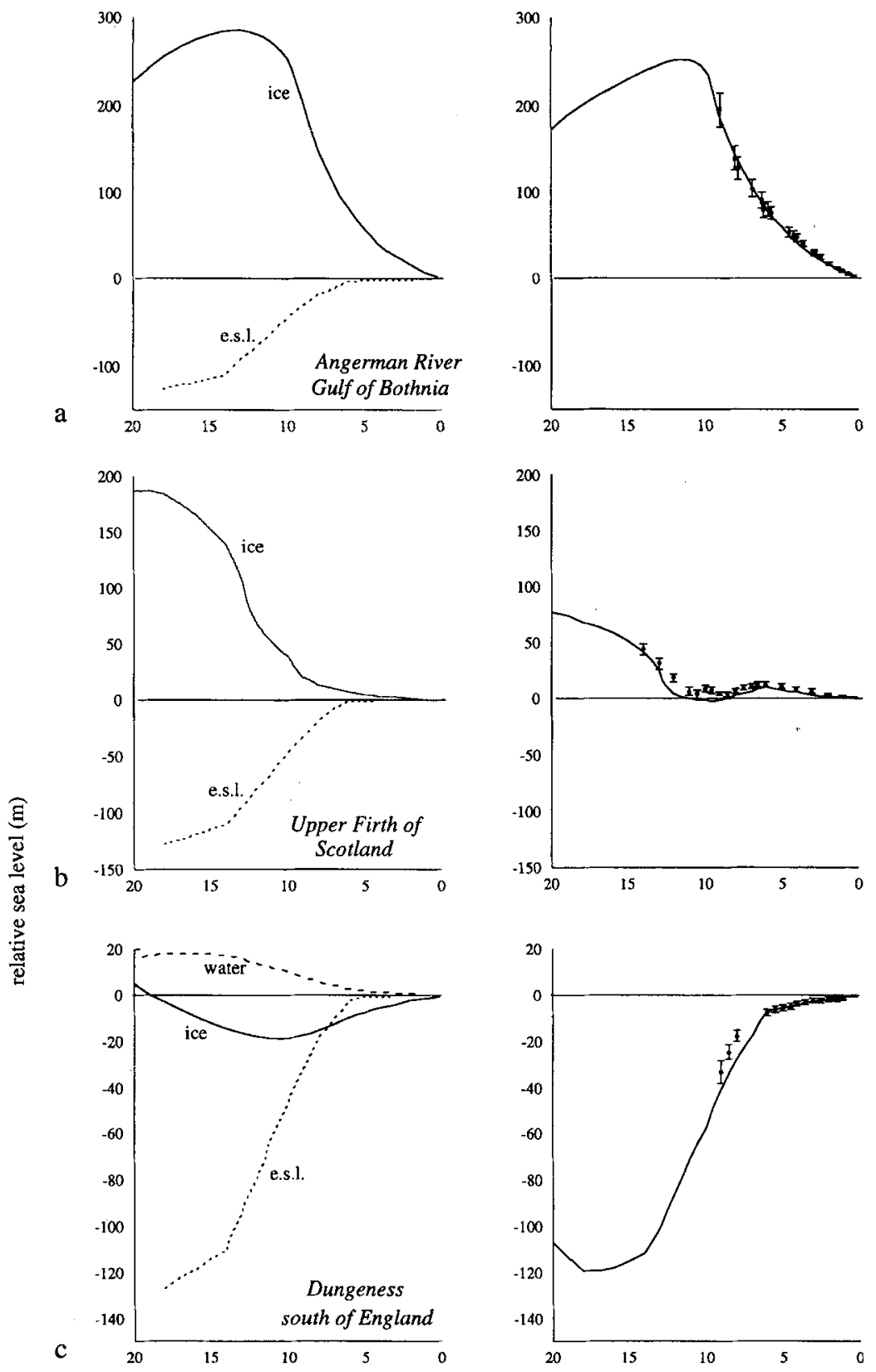

d
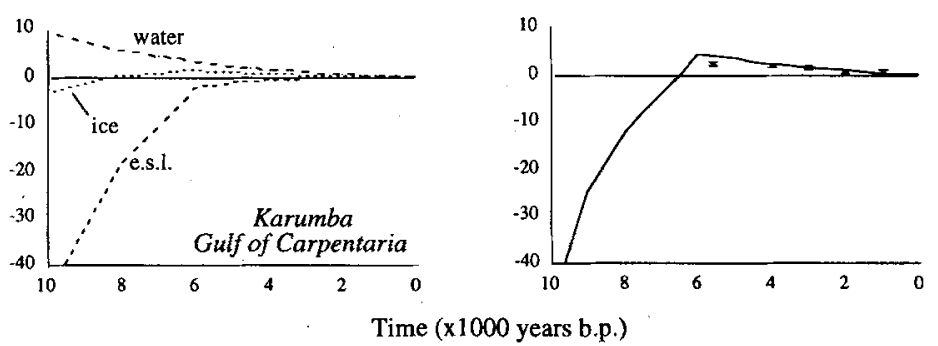
the deforming planet. This 'glacio-isostatic correction' is a function of the elastic and viscous properties of the Earth, as well as of the temporal and spatial distribution of the ice sheets. This term is also most important for the former areas of glaciation where the crust has been depressed by the ice load. As the ice melts, the crust rebounds at a rate determined by the mantle viscosity and by the ice thickness. For large ice loads, crustal rebound exceeds the eustatic change so that sea-level appears to fall relative to the land. This is seen in the Gulf of Bothnia, for example, where there are raised shoreline features whose ages increase with height (FIGURE 1a). Rates of relative sea-level fall in excess of $20 \mathrm{~mm}$ per year have been inferred for some localities. Because of the viscous nature of the mantle flow, the rebound and relative sea-level change continues long after deglaciation has ceased. For small ice sheets such as that formerly over Britain, or regions near the margins of the ice sheets, as in southern Norway or Denmark, the crustal rebound and the change in relative sea-level was much smaller, the latter remaining within a few tens of metres of the present level since Late Glacial time (FIGURE 1b). Here, the crustal rebound is less than for the sites closer to the former centres of ice loading; it is of comparable magnitude but of opposite sign to the eustatic contribution. Further away again, beyond the areas of former glaciation, the response of the crust to the removal of the ice is one of subsidence in reaction to the flow of the underlying mantle material towards the formerly loaded areas. Here sea-level appears to be rising to the present, even though all melting ceased much earlier. This is the case, for example, in southern England, or along the Atlantic margin of France (FIGURE 1c). In the Aegean, sea-level also appears to be rising throughout the Holocene because of the crustal response to the melting of, primarily, the Scandinavian ice sheet.

The hydro-isostatic term $\Delta \zeta_{w}(\varphi, t)$ describes the contribution to the sea-level change from the meltwater loading of the crust and the associated change in gravitational potential. The term is a function of the Earth's elastic and viscous parameters (its rheology) and of the relative sea-level change itself, as well as of the shifting coastlines. Small compared with the maximum glacio-isostatic and eustatic terms, it becomes dominant in areas away from the ice sheets at postglacial times. At continental margin sites, the characteristic hydro-isostatic signal is a falling sea-level as the sea floor slowly subsides under the new water load (FIGURE 1d), but only for about the past 6000 years does it dominate over the other contributions; relative sea-levels will have been higher than today from about 6000 years b.p. to the present. The amplitudes of the highstands are small, up to about $3 \mathrm{~m}$ depending on the coastal geometry, but in flat and low-lying areas such as lower Mesopotamia or the southern shore of the Gulf of Carpentaria, this can have led to substantial inundation in mid-Holocene time.

For the Aegean region all three contributions to the isostatic term (3) are important, as FIGURE 2 illustrates, for a model discussed in detail elsewhere (Lambeck 1995a). FIGURE 2a illustrates the variation in the rigid term $\Delta \zeta_{r}$ over the region at 18,000 and 10,000 years b.p. This corrective term is positive, indicating that the gravitational pull on the water by the ice over Fennoscandia is important out to distances of about $2000-2500 \mathrm{~km}$ from the centre of the ice load. FIGURE $2 \mathrm{~b}$ illustrates the ice load term $\Delta \zeta_{i}$ for the same two epochs. This term is negative in this region of crustal subsidence upon ice unloading ( $c f$. FIGURE 1c), and partly cancels out the rigid term. The water-load term is illustrated in FIGURE 2c. This correction is mainly positive over the land and negative at sea, and the contours tend to follow the coastline, their relatively smooth character illustrating the filtering effect of the elastic lithosphere on the crustal deformation.

Together, the three corrective terms in the Aegean region result in sea-level at the time of the Last Glacial Maximum varying between -115 and $-135 \mathrm{~m}$, compared to the eustatic value of about $-125 \mathrm{~m}$ for this epoch. At 10,000 years ago the predicted sea-levels over the region vary from -43 to $-55 \mathrm{~m}$, compared to a eustatic level of about $-43 \mathrm{~m}$. The actual emplitudes and details of the spatial patterns depend on the parameters used to describe the ice load and the Earth's rheology but the overall trends and magnitudes are representative of the departures of the sea-level change from the simple eustatic approximation.

Other than predicting temporal and spatial changes in sea-level, the glacio-hydro-isostatic model also predicts the location of past shorelines and palaeo water depths if the present 

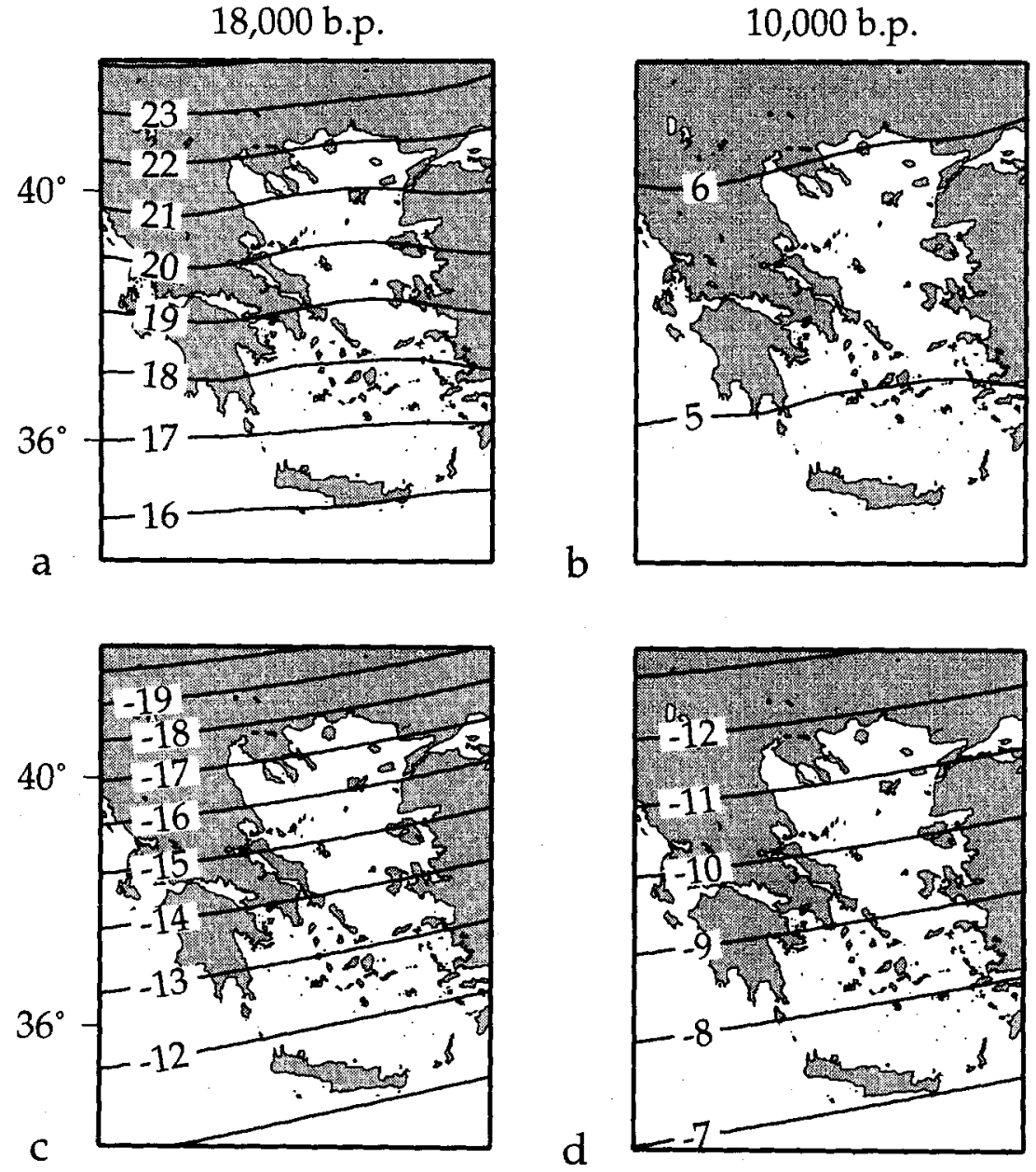

FIGURE 2. Spatial variation of the rigid (a $\&$ b), glacioisostatic ( $\& \mathrm{~d})$ and hydro-isostatic (e \& f) contributions to relative sea-level change across Greece and the Aegean at 18,000 (a, c, e) and $10,000(\mathrm{~b}, \mathrm{~d}, \mathrm{f}) B P$. The first two components are for the northern hemisphere ice-sheet only; the third component is for the meltwater from both hemispheres.
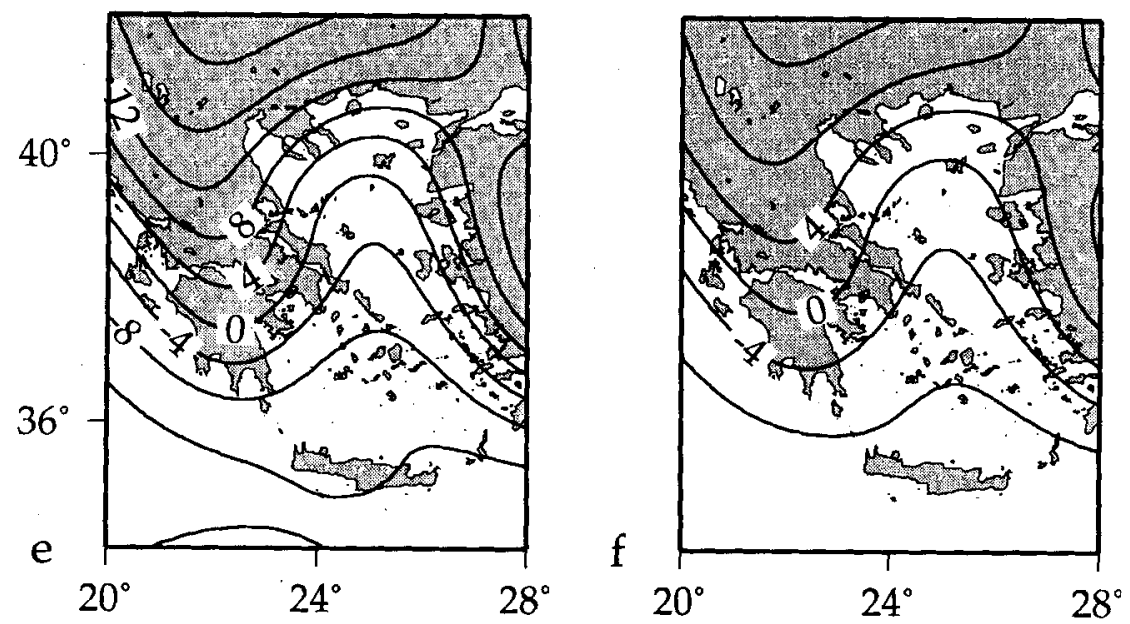
water depth $H_{o}(\varphi)$ at location $\varphi$ is known. That is, the water depth at a time $t$ and position $\varphi$ are related to $\Delta \zeta(\varphi, t)$ by

$$
H(\varphi, t)=H_{o}(\varphi)-\Delta \zeta(\varphi, t)
$$

To evaluate the spatial and temporal distribution of sea-level and shoreline change during a glacial cycle several requirements have to be met. These include:

- A model of the eustatic sea-level function $\Delta \zeta_{e}(t)$ - usually inferred from the sea-level observations themselves because independent estimates of the volumes of the former ice sheets do not exist. These estimates are derived from localities where the isostatic corrections are believed to be small such that they can be estimated in an iterative manner (Nakada \& Lambeck 1988). Many published estimates of the eustatic sea-level curve have ignored the isostatic contributions: the resulting errors may be particularly important when estimates are based on sea-level data from the North Atlantic margin of the United States of America where the glacio-isostatic effects are significant.

- A detailed description of the growth and decay of the ice sheets, required to calculate the glacio-isostatic term. For localities near or within former ice-sheet limits, a detailed description of the evolution of the ice load is required whereas for regions away from the ice margins, such as the Mediterranean, approximate spatial descriptions of the changing ice-sheets suffice.

- A model of the Earth's rheology, describing the response of the planet to surface loading on time-scales of thousands of years. The elastic behaviour of the Earth is well known from seismological studies but the viscous properties, less well known, are estimated from comparisons of isostatic-model predictions with observations from regions of otherwise tectonic stability.

- A description of the coastline geometry and the shallow-water bathymetry, required to estimate the palaeo-shorelines through the relation (5). The time-dependence of this coastline must also be considered in the calculation of the hydro-isostatic term, particularly if high accuracy local solu- tions are sought for a region such as the eastern Mediterranean. This is. usually achieved by iterating between equations 4 and 5.

\section{The eustatic sea-level curve}

Published estimates of the eustatic sea-level curve are varied, the reasons for which are several. Some are associated with interpreting of the observational evidence. Corals, as for example used to estimate the sea-level curve at Barbados (Fairbanks 1989), provide estimates of a lower limit to the sea-level curve, while submerged in situ terrestrial vegetation such as fresh-water peats or tree stumps provide an upper limit. Estimates based on the depth-age relations of molluscs are often unreliable: their original depth-range relative to mean sea-level is large, or they may have been transported from their growth position to new levels. The different published results may also reflect the neglect, or inadequate elimination, of the glaciohydro-isostatic factors. For example, a number of the still-quoted estimates used in sea-level studies in the Mediterranean are based on old observations from the Atlantic coast of North America (e.g. Curray 1965; Milliman \& Emery 1968) where the relative sea-level is influenced by the glacio-isostatic rebound of the Laurentide region such that the observed levels in Late Glacial time generally lie above the eustatic curve ( $c f$. FIGURE 1c).

Across continental margins, corrections for the hydro-isostatic factors in Late Glacial times are also significant, reaching $20-30 \mathrm{~m}$ at the time of the Last Glacial Maximum (Lambeck \& Nakada 1990). Observations from islands far from both continental margins and ice sheets provide better estimates of the eustatic sea-level, but even these are not immune to the isostatic factors (e.g. Nakada \& Lambeck 1987; Mitrovica \& Peltier 1991). As the establishment of a global eustatic sea-level curve requires models for the isostatic corrections, the procedure adopted here is to apply the model (4) to areas of the world where other tectonic processes producing vertical movements are believed insignificant, or where corrections for these movements can be independently made (e.g. Lambeck 1993; 1995a). FIGURE 3 illustrates the best estimate of the eustatic sea-level curve since the time of the Last Glacial Maximum; it is based on analyses of sea-level change from locations far from 


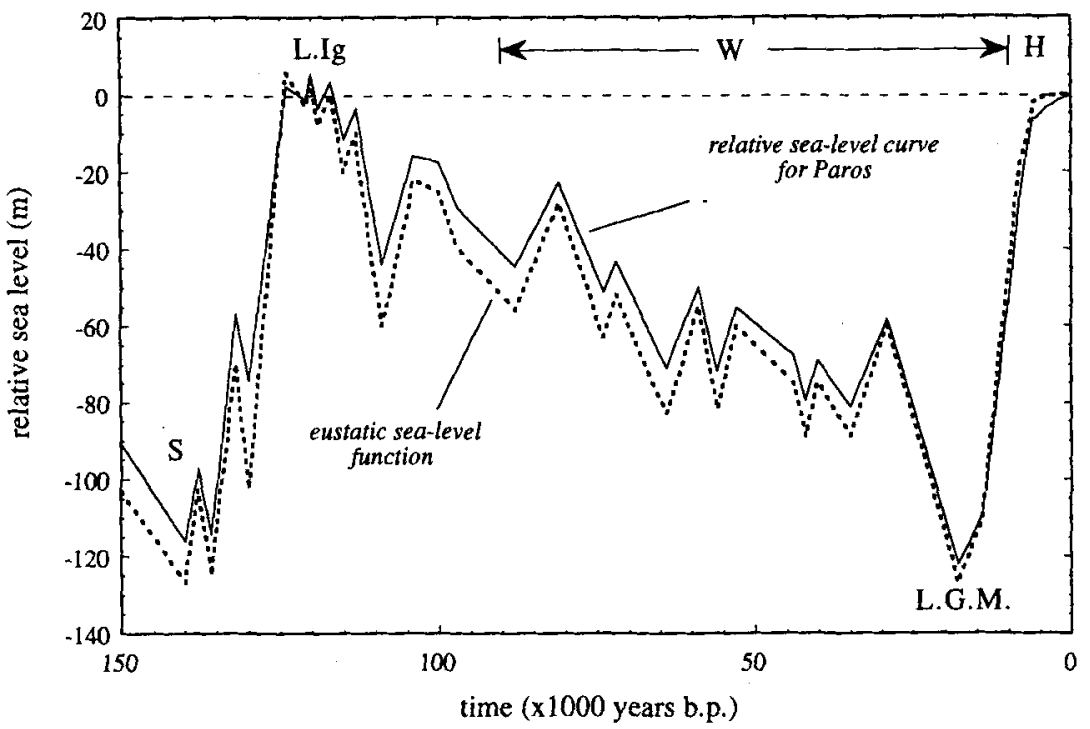

FIGURE 3. Estimate of eustatic sea-level change (dashed curve) for the past 150,000 years based on observed shore-line age-depth relations and models of ice-sheet melting for the last 18,000 years and on oxygen isotope data from deep-sea cores (after Shackleton 1987) for the earlier period. The solid curve represents the predicted sea-level variation for Páros in the Cycladean island group (this prediction is discussed below). (L.G.M. = Last Glacial Maximum, L.Ig = Last Interglacial, $S=$ Saalian Glacial Maximum, $W=$ Weichselian or Mousterian, $H=$ Holocene).

the ice sheets, along the continental margin of Australia and elsewhere. This result is consistent with the upward coral reef growth-rate curve from Barbados (Fairbanks 1989) when that is corrected for the isostatic perturbations, as well as with the results from the rapidly uplifting Huon Peninsula of Papua New Guinea (Chappell \& Pollach 1991) once tectonic and isostatic corrections are applied. Major contributions to this globally integrated rate of melting comes from the Laurentian, Fennoscandian, Barents Sea and Antarctic ice sheets.

One characteristic of this sea-level curve is that the bulk of melting ceased at about 6000 years ago when the last ice from Laurentia vanished. (The Fennoscandian ice sheet vanished soon after 9000 years b.p.) But a small amount of additional meltwater continued to be added into the oceans after this time, probably from a small reduction in the Antarctic ice volume, so as to raise the eustatic level by about $2-3 \mathrm{~m}$ during the past 6000 years (Nakada \& Lambeck 1988). Another characteristic of this eustatic sea-level curve is that the function is devoid of rapid oscillations. Detailed studies from the same or close-by sites of sea-level change during the past 6000 years indicate little evidence for such oscillations once the major ice sheets have melted or approached their present volumes (Chappell 1983; Hyvärinen 1980). Likewise, estimates of the eustatic sea-level function for the period between 12,000 and 6000 years b.p. suggest that any oscillations in this interval are likely to be less than about $2 \mathrm{~m}$ (Lambeck 1993; in press).

Because of the viscous nature of the response of the Earth to changing surface loads, the isostatic contributions to the sea-level change are effective long after the changes in loading have occurred, as is best seen in the on-going uplift of the Fennoscandian area (FIGURE 1a). The prediction of sea-level at any period, therefore, requires information about the earlier ice sheet histories. For studies of sea-level near the time of the Last Glacial Maximum, this requires a knowledge of the ice sheets during their growth phase. As this information is generally scanty, reliable models for the changing volumes of the individual major ice sheets before the Last Glacial Maximum do not exist. Estimates of the early eustatic sea-level curve also cannot be established from sea-level information alone because of the great paucity of older observations preserved in the geological record and 
which can be reliably dated. Instead, an approximate estimate of this function is obtained from oxygen isotope records of the sea-floor sediments scaled by the more directly observed changes for the past 18,000 years (e.g. Shackleton 1987; Chappell \& Shackleton 1986). FIGURE 3 illustrates this result back to 150,000 years b.p. The last time sea-levels were near their present value occurred about 120,000 years ago when climate and ice volumes were last similar to those of the latter part of the Holocene. In between these two interglacial periods, the oxygen isotope information shows the peak glacial conditions persisting for only a relatively short interval, although for much of the time between about 70,000 years b.p. and the Glacial Maximum, ice volumes significantly exceeded those of today such that the global sea-levels did not rise above $40-50 \mathrm{~m}$ below present level during this interval.

\section{Ice sheet models}

The main sources of meltwater were the icesheets over North America, northern Europe including the Barents Sea, and a larger-thanpresent ice-sheet over Antarctica. These ice caps contributed about 70,25 and $25 \mathrm{~m}$ respectively to the eustatic sea-level change since the time of the Last Glacial Maximum. The retreat of the northern ice sheets is reasonably well constrained over the continents by geological and geomorphological observations (e.g. Denton \& Hughes 1981), but the extent over the shallow seas such as the Barents Sea is less well known, although observations of raised shorelines from islands in such areas can be used to constrain the ice volumes (Lambeck 1995b). Even over the continents the ice thickness is usually not well constrained from independent observations and is usually inferred from ice-model considerations and from the interpretation of raised shorelines within the limits of the areas of former glaciation (e.g. Tushingham \& Peltier 1991; Lambeck 1993). Observational evidence of sealevel change within and immediately outside the former areas of glaciation has generally been sufficient to arrive at consistent northern ice sheet models since the time of the Last Glacial Maximum. More problematic has been the estimation of the volume changes in the Antarctic ice sheet since this time. Some observations of raised shorelines from the margin of this ice sheet suggest a reduction in ice volumes since the glacial maximum (Zwartz et al. in preparation) but the evidence is inadequate to establish a quantitative model. Instead, inferences of past Antarctic ice volumes are based on more indirect indicators, such as the need for the total ice volume to correspond to the observed eustatic sea-level curve and from the pattern of Late Glacial and Postglacial sea-level change in southern latitudes.

\section{Earth model parameters}

Essential to predictions of the isostatic sea-level corrections is a model for the elastic and viscous properties of the Earth. The elastic parameters and the radial density distribution are obtained from the analysis of seismic wave velocities through the planet, quantities sufficiently well known for the elastic deformation to be calculated and tested against known shortperiod tidal deformations of the Earth. The viscosity structure, less well known, has to be inferred from the isostatic analysis itself. It is this geophysical problem that has provided the major impetus for the study of past sea-level (Cathles 1975; Peltier \& Andrews 1976; Nakada \& Lambeck 1987; Mitrovica \& Peltier 1993). The assumed viscosity models are relatively simple, comprising a mantle with a few layers of different viscosity values. For most predictions of palaeosea-levels and shorelines, a three-layered model gives adequate predictive capabilities; studies from different localities produce largely consistent results (Lambeck et al. 1990; Lambeck \& Nakada 1990; Lambeck 1993). Such models comprise an essentially elastic lithosphere of 60-80 km thickness, an upper mantle (down to the $670 \mathrm{~km}$ depth seismic discontinuity) with an effective viscosity of (25) $10^{20} \mathrm{~Pa} \mathrm{~s}$, and a lower mantle with a viscosity of about $10^{22} \mathrm{~Pa}$.

Whether the lithospheric thickness and mantle viscosity parameters are laterally uniform is an important geophysical question and some evidence suggests they may vary from region to region, depending on the tectonic history of the crust. For tectonically active areas such as the Aegean, the lithosphere can be expected to be thinner than for the stable tectonic terrains of northern Europe; likewise, the upper mantle viscosity for the tectonic regions are likely to be less in the Aegean as well. Ideally the mantle parameters should be estimated from sea-level data from the region of interest. 
But for the Aegean the observational data-base is limited and, furthermore, the evidence is contaminated by tectonic contributions. But by a largely fortuitous trade-off between the earth-model parameters - sea-level predictions for thin-lithosphere, lower-mantle-viscosity models are very similar to those for thicklithosphere, higher-mantle-viscosity models (Lambeck 1995a; Lambeck et al. 1996) and it appears that parameters estimated from wellconstrained rebound problems for northern Europe constrain reasonably well the sea-level change models for the eastern Mediterranean. Until a better observational record is established, the earth models for the northern European region are used for the Aegean predictions below.

\section{The Aegean region}

Observations of sea-level change

The evidence for sea-level change along the Greek coastline is inferred from a variety of geological and archaeological indicators, the latter being more plentiful for about the last 4000 years. The archaeological evidence has been examined in detail by Flemming (1978), particularly for the coast of the Peloponnese and southwestern Turkey. The evidence consists of the positions of structures that, at their time of construction, are believed to bear a known relation to the position of the sea. In other instances, the evidence provides only constraints on sea-level. For example, offshore from Franchthi Cave, near Koilás ${ }^{2}$ in the southern Argolis Peninsula, a Neolithic site points to the sea having been at least $11 \mathrm{~m}$ lower than today between $7610 \pm 150$ and $6220 \pm 130$ years b.p. (Jacobsen \& Farrand 1987; van Andel 1987). Likewise, at Saliagos on the Cycladean island of Andipáros, now-submerged Early Bronze Age remains point to sea-levels before 5000 years b.p. having been at least $5 \mathrm{~m}$ lower than today (Morrison 1968).

The geological evidence for past sea-levels in the Aegean and adjacent areas takes a number of forms, including the depths of submerged terrestrial or lagoonal vegetation and sediments, inferences drawn from seismic reflectors in shallow offshore sediments, and the age-height relation of marine solution notches. The evi-

2 Spelling of place-names generally follows that of the Times Atlas of the World. dence from the lagoonal and terrestrial sediments comes mainly from the shallow upper regions of the Gulfs of Messenia (Kraft \& Rapp 1975), Lakonia and Argolis (Kraft et al. 1977), and from the Bay of Navarone (Kraft et al. 1980) near Pylos, all in the Peloponnese. At these sites sea-levels appear to have been rising relative to the land for at least the last 10,000 years, at rates that may have been temporally and spatially variable, although the quality of the data is generally insufficient to quantify more than the general trends. An important inference from seismic stratigraphy is that sea-level at about 18,000 years ago offshore from the southern Argolis Peninsula was about $120 \mathrm{~m}$ lower than today (van Andel \& Lianos 1983). The solutionnotches produced by marine borers are preserved only when rapid uplift events occur such that the notch, formed at about mean sea-level, is lifted beyond the tidal range. Well-developed sequences occur, for example, in western Crete, Rhodes, Karpathos and the Kythera islands (Flemming 1978; Thommeret et al. 1981) as well as in the Gulf of Corinth (Pirazzoli et al. 1994), at elevations of up to $10 \mathrm{~m}$ and with estimated ages of up to $4000-5000$ years.

\section{Tectonic contributions to sea-level change}

Tectonic movements and deformation of the crust occur over a wide spectrum of length and time-scales, from the slow and nearly uniform global plate tectonic motions to localized and sudden earthquake displacements. These movements are surface expressions of geophysical mechanisms operating internally to the Earth, and their records contain much information on the processes shaping the planet. The geological record provides many examples of these surface displacements, particularly in the vertical direction which contribute to the relative change in the positions of the land and sea surfaces. The eastern Mediterranean is a region of active tectonics and Greece in particular is one of the most rapidly deforming continental areas on Earth (Jackson 1994). Other examples of vertical movements occur in response to changes in the surface loads when crustal material is eroded and deposited elsewhere. This process, similar to the glacial unloading problem, is usually more localized. In Greece, the sediment transport into the shallow bays and gulfs is comparatively small and this loading contribution is unlikely to have been impor- 
tant on time-scales of 10,000 or so years. The deposition of sediments may, however, have contributed locally to the build-up of the land surface and migration of shorelines in some bays.

Usually the processes producing these vertical movements are only qualitatively understood; quantitative models with sufficient accuracy to correct observed sea-level oscillations for the tectonic components rarely exist. Analyses of relative sea-level observations for isostatic parameters or for the eustatic function are therefore less accurate if tectonic movements of the crust are also important. But some separation is made possible by the different characteristics of the two contributions to sealevel change. While the tectonic displacements on the short term may be episodic and localized, they persist for long periods of time, and on time-scales of $100,000-1,000,000$ years, they appear as slow but persistent movements. In contrast, changes associated with the growth and decay of the ice sheets are relatively uniform and global on short time-scales $(\sim 1000$ years), but they are of a cyclic nature on the longer time-scale. Thus, in the absence of changes in ocean volume, a tectonic uplift or subsidence of $1 \mathrm{~mm} /$ year means that shorelines formed 10,000 years ago would now be $100 \mathrm{~m}$ above or below present sea-level. An indicator of long-term tectonic stability is therefore provided by the present position of the Last Interglacial shoreline which formed about 120,000 years ago. Ocean and ice volumes at that time were similar to those of today, and sea-levels were near their present level. In the Mediterranean Sea, the Last Interglacial shoreline known regionally as the Tyrrhenian Shoreline - occurs in many localities to within a few metres above present sea-level. This is reported to be the case, for example, in the upper regions of the Gulfs of Messenia, Lakonia and Argolis of the southern Peloponnese (Kelletat et al. 1976; van Andel 1987). Although a new evaluation of the evidence is desirable, little vertical tectonic movement appears to have occurred in these localities during the past 120,000 or so years. Along the southern shore of the Gulf of Corinth, where the Last Interglacial shoreline is found at elevations of 30-70 $\mathrm{m}$ (Keraudren \& Sorel 1987; Collier et al. 1992), tectonic uplift at average rates of 0.25 to 0.6 $\mathrm{mm}$ per year appears to have occurred during the same interval. Thus, where this shoreline can be identified, it becomes possible to determine whether vertical crustal tectonics has been important and - if it has - to correct for it on the not always substantiated assumption that the tectonic rates have been uniform through time for at least the last 120,000 years.

\section{Predicted sea-levels in the Aegean region}

Generally, the sea-level observations for Greece and the Aegean are inadequate to estimate both the parameters describing the glacio-hydroisostatic theory and the tectoric movements of the crust. Instead, the former part is estimated using the above outlined theory and model parameters; then it is tested against data from areas inferred to be tectonically stable from observations of the position of the Last Interglacial shoreline. If these comparisons are satisfactory, then predictions are also made for the tectonically active sites to estimate the rates of vertical uplift or subsidence (Lambeck 1995a).

FIGURE 4 illustrates the predicted past sealevels across the region in the form of contours of equal relative sea-level position for a few selected epochs. The contours at 18,000 b.p., for example, indicate the amount by which sealevels at that time were lower than the present day mean sea-level. For all epochs there is a subsidence of the offshore areas of the Aegean, Ionian and Mediterranean Seas relative to the mainland, the contour values increasing with distance from the mainland. This reflects the hydro-isostatic effect with subsidence of the sea floor and uplift of the land areas ( $c f$. FIGURE 2). Superimposed upon this is a north-south trend imposed by the glacio-isostatic effect, mainly from the Fennoscandian ice load in Late Glacial time ( $c f$. FIGURE 2). Throughout the region sea-level continues to rise, initially rapidly as the ice sheets are disintegrating and then relatively slowly for the last 6000 years when the main contributions to the change come from the isostatic component. FIGURE 5 illustrates the changes in sea-level at four sites in the region. Predictions for the areas of Thrace and Crete (FIGURE 5a) differ because Crete is further from the ice sheet and the hydro-isostatic effect is that of an island, whereas the prediction for Thrace is characteristic of a continental margin site. At the time of the Last Glacial Maximum the predictions for the two sites differ by about $20 \mathrm{~m}$, with the Thrace curve lying above the Crete prediction at all times. The east-west 
18,000 b.p.

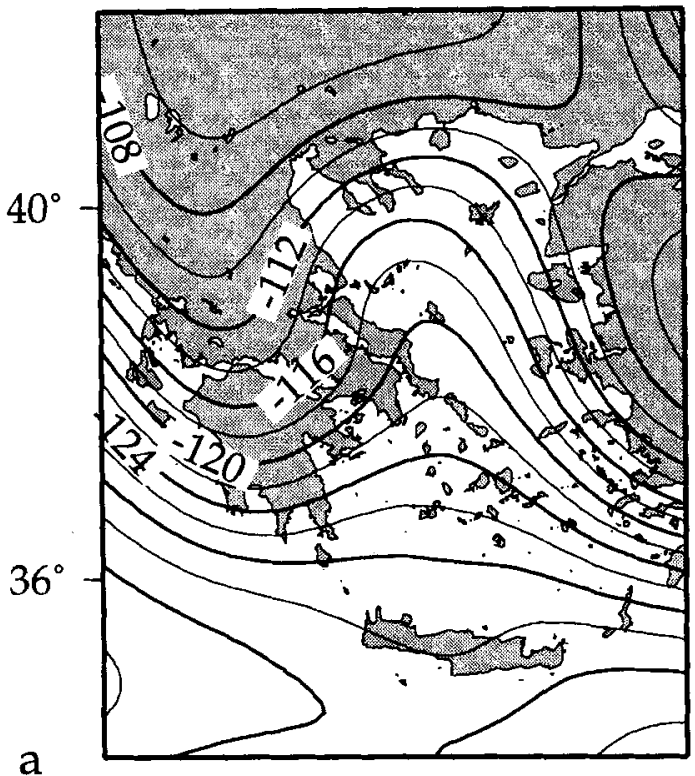

6,000 b.p.

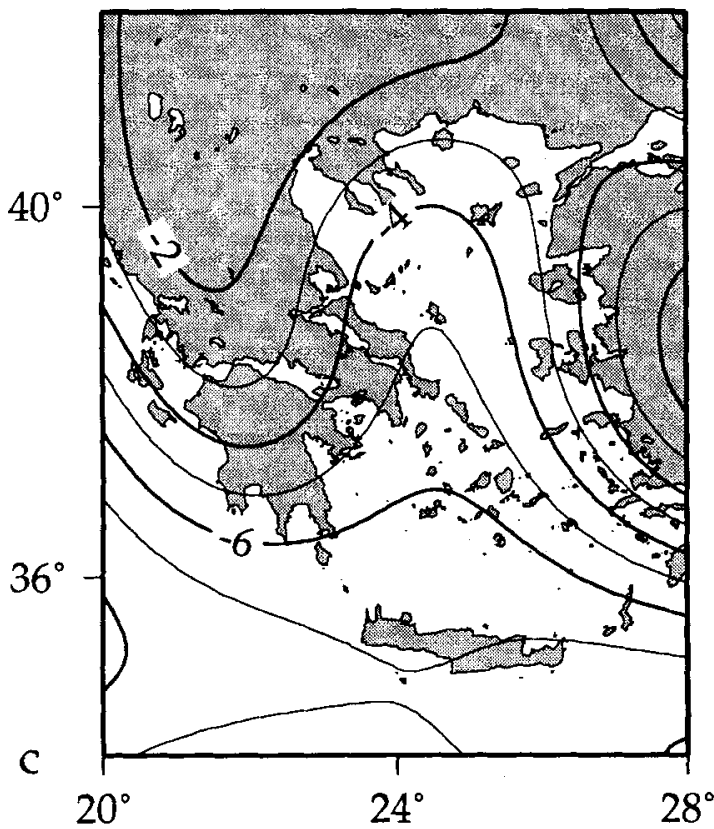

10,000 b.p.

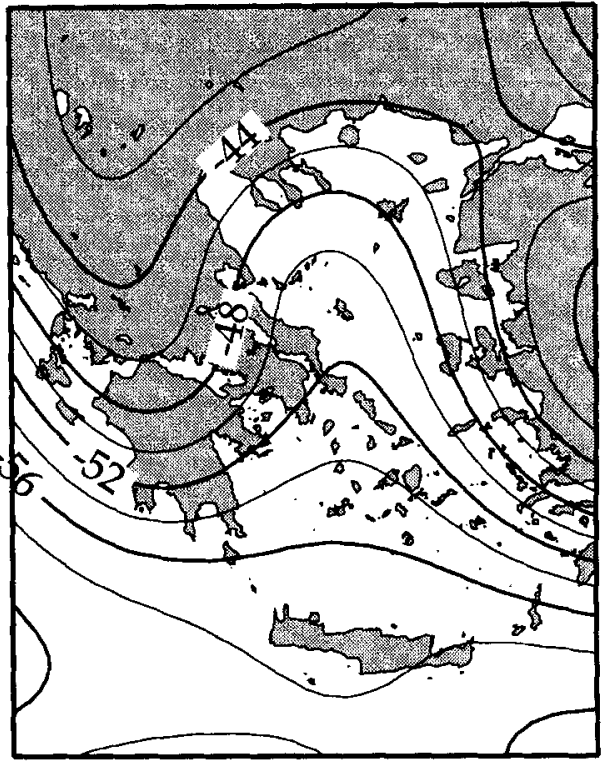

2,000 b.p.

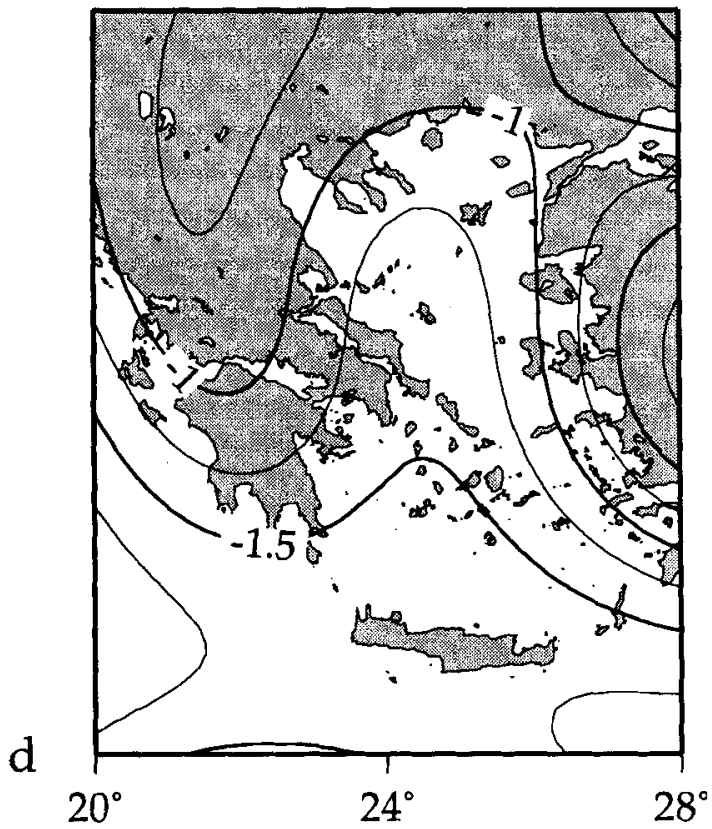

FIGURE 4. Predicted relative sea-level change for Greece and adjacent areas at (a) 18,000 BP, (b) 10,000 $\mathrm{BP}$, (c) $6000 \mathrm{BP}$, (d) $2000 \mathrm{BP}$. The contours represent the position of mean sea-level at these epochs relative to the present mean level. 


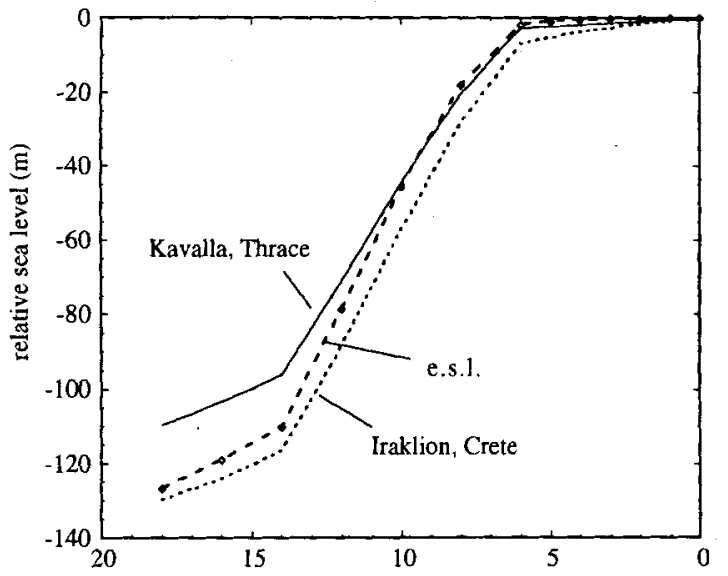

a

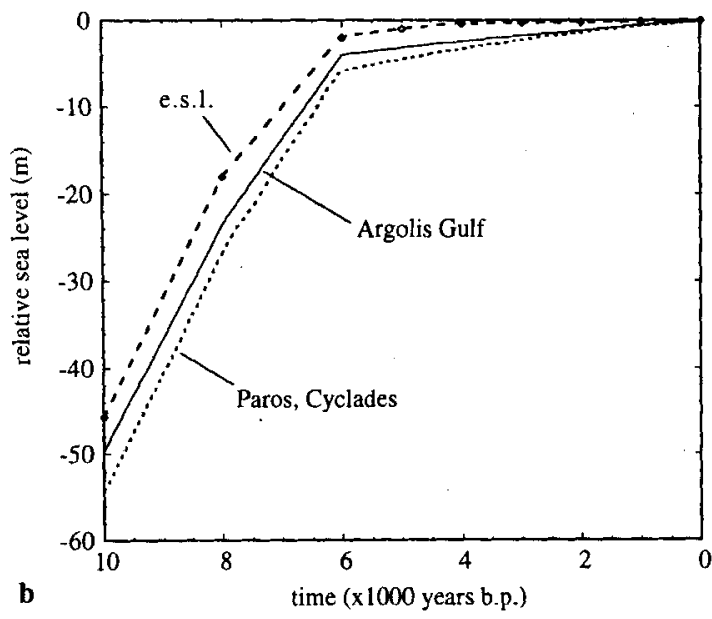

FIGURE 5. Predicted sea-level at four sites since the time of the Last Glacial Maximum compared with eustatic sea-level.

a Sites near Kavalla (Thrace) and Iraklion (Crete) illustrate the north-south variability resulting mainly from the glacio-isostatic effect.

b Sites in the Argolis Gulf and the Cycladean island of Páros illustrate the east-west variability resulting mainly from the hydro-isostatic effect. (Note the different time-scales for the two illustrations.)

variability is illustrated by the comparison for a site in the Argolis Gulf with a site in the Cycladean island group (FIGURE 5b). The east-west spatial variation, largely the result of the hydro-isostatic correction, remains significant, about $5 \mathrm{~m}$ at 10,000 years b.p. At both sites the predictions lie well below the eustatic sea-level function.

If no other tectonic processes were active, at no epoch, particularly during the past 6000 years, are the sea-levels here predicted to have risen above their present levels. As a whole, the region would appear to experience a gradual subsidence at average rates ranging from about -0.6 to $-1.2 \mathrm{~mm}$ per year. This is largely consistent with the observations of an apparent encroachment of the sea in the Argolis, Lakonia, Messenia, and Navarone Bay areas. Tectonic subsidence does not appear to have been significant, in agreement with the observation of the location of the Tyrrhenian shoreline at only a few metres above present sea-level at several of these localities. The model also predicts a rising sea-level throughout the Cycladean Islands, consistent with the observation of the submerged Early Bronze Age site near Saliagos (Morrison 1968); there is no need to invoke tectonic subsidence of this area of sea floor.

Where the observations point to relative uplift the estimated rates of tectonic displacements are increased over and above the rates that would be inferred if the glacio-hydro-isostatic corrections are ignored. Likewise, areas of small apparent subsidence, at rates that are less than the isostatic rates, will also be undergoing tectonic uplift albeit at slow rates. The main area of systematic and substantial tectonic uplift forms an arc extending from Rhodes in the east to Karpathos, Crete, Kythera and the southernmost peninsulas of the Pelopoinnese (Lambeck 1995a). This pattern follows closely the convergent boundary between the major tectonic units in the area and the maximum rate of uplift, exceeding $4 \mathrm{~mm}$ per year, occurs in southwestern Crete close to the plate margin. The other area of major tectonic uplift occurs along the southern shore and eastern end of the Gulf of Corinthos, with uplift-rate estimates approaching $1.5 \mathrm{~mm} /$ year. For cer tral Evvoia, the rates of uplift are also estimated to be about 1$1.5 \mathrm{~mm}$ per year. Elsewhere in the Peloponnese and Aegean no systematic patterns of tectonic uplift or subsidence appear; those movements are either smaller in amplitude or of shorter horizontal length scales than the glaciohydro-isostatic changes. In the south of the Argolis Peninsula near Porto Kheli, subsidence appears to have occurred at a rate of about 1 $\mathrm{mm}$ per year for the last few thousand years (Flemming 1978) but just to the north, at the Franchthi site, little tectonic movement appears to have occurred if the van Andel \& Lianos (1983) estimate of Last Glacial Maximum sea-level of about $-120 \mathrm{~m}$ is correct. 


\section{Palaeo shorelines in the Aegean region}

Once a predictive model for sea-level exists that adequately reflects the observed changes, it becomes possible to predict the location of shorelines through time using the relation (5) for areas where tectonic movements are inferred to have been small - as appears to have been the case for the central Aegean islands and much of the Peloponnese. As the topography and water depth vary much more rapidly than the sealevel change function, a much higher spatial description of the former is required for precise palaeogeographic reconstructions. The highresolution data compiled here are based on:

- digitized bathymetric charts for the central Aegean sea-floor at scales of 1:100,000 and 1:150,000 (HNHS 1993),

- a 500-m resolution digital terrain model for central Greece and the Aegean islands provided by the National Technical University in Athens, and

- for an area around Franchthi on the Argolid Peninsula, digitized data (including bathymetry) from the 1:50,000 topographic map for the area (HMGS 1992). Beyond the marine areas covered by the digitized $1: 100,000$ and $1: 150,000$ maps, the bathymetry included in the Greek digital terrain model is used.

These three data-sets have been combined and gridded on to a $0.01^{\circ}$ grid using the Delaunay triangulation and natural neighbour element methods (Sambridge et al. 1995). Bathymetric features larger than about $0.02^{\circ}$ (or about $2 \mathrm{~km}$ ) are generally well resolved in this gridded database.

\section{Late Palaeolithic and Neolithic shorelines}

Results for these palaeoshorelines are illustrated in FIGURE 6 for the Aegean region based on the above bathymetric data base. At the time of the Last Glacial Maximum, as pointed out by van Andel \& Shackleton (1982), much of the area of now-shallow waters would have been exposed at this time. For example, the central part of the Saronikós Gulf would have been a freshor brackish water environment, and the area between Evvoia and Ellas -- forming the presentday northern and southern parts of the Evvöikós Gulf and the Petalion Gulf - would have consisted of a series of topographic depressions beyond marine influence. Also the Cycladean group of islands formed an extensive land area; extending from Andros in the north to Ios in the south over a distance of about $160 \mathrm{~km}$. To the north, beyond the area illustrated in FIGURE 6, large tracts of the Thermaïkós Gulf were exposed, and the plain of Thrace extended more than $60 \mathrm{~km}$ to the south of the present shoreline. The broad and shallow area between Limnos and Turkey would also have been exposed, cutting off the Sea of Marmara from marine influence: (See FIGURE 4 for the predicted sea-level change in these areas.)

At this time of maximum glaciation the 'Cycladean Island' effectively divides the Aegean Sea into two: the Aegean Sea proper in the north from the Mirtoan Sea and the Sea of Crete in the south and southwest. The two basins are connected via a narrow channel $(\sim 6 \mathrm{~km}$ wide) between Evvoia and Andros in the north and by further channels ( $12 \mathrm{~km}$ wide) between the islands of Amorgós and Kalimnos. On the Cycladean Island itself, a broad central and relatively flat plain was punctuated by hills and mountains that now form the residual islands. The average height of the plain was about 15$20 \mathrm{~m}$ above sea-level; topographic lows within it, between Náxos and Mikonos, for example, could have held shallow freshwater environments. To the west, the islands of Milos, Sifnos, Sérifos and Kithnos remained separate both from each other and from the mainland, although the minimum widths of the sea passages were considerably less than today. The single entity made by the islands of Milos, Kimolos and Poliaigos, for example, were separated from the Cycladean landmass by relatively shallow $(<100$ m) channels with a minimum water-crossing distance of about $8 \mathrm{~km}$ (FIGURE 7). Thira (Santorini) would have been separated from the main island landmass by less than $5 \mathrm{~km} .{ }^{3}$ Elsewhere, the coastal plains at the time of the Last Glacial Maximum are wider than today, as in the Argolis Gulf, around the Argolis Peninsula (FIGURE 8) and along the eastern margin of the Aegean Sea.

Initially this geography changes only slowly; even though the large ice sheets are beginning to melt, the delayed response of the Earth means that the actual sea-level change at these sites is relatively slow. By 14,000 years b.p., the coastal geometry has changed only little from

\footnotetext{
3 No attempt has been made to reconstruct Thira to its pre-eruption topography.
} 
a

$18000 \mathrm{BP}$
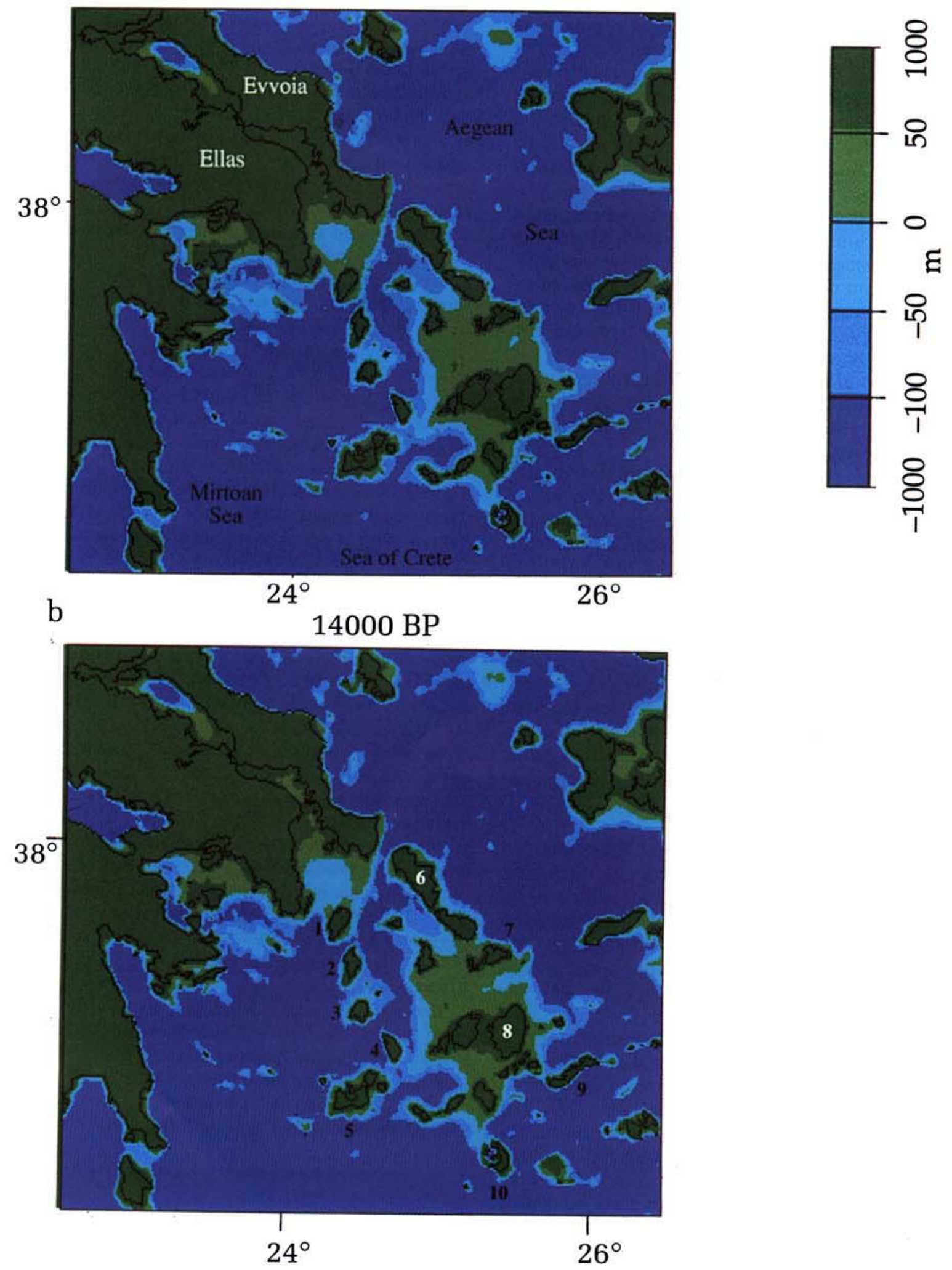
C
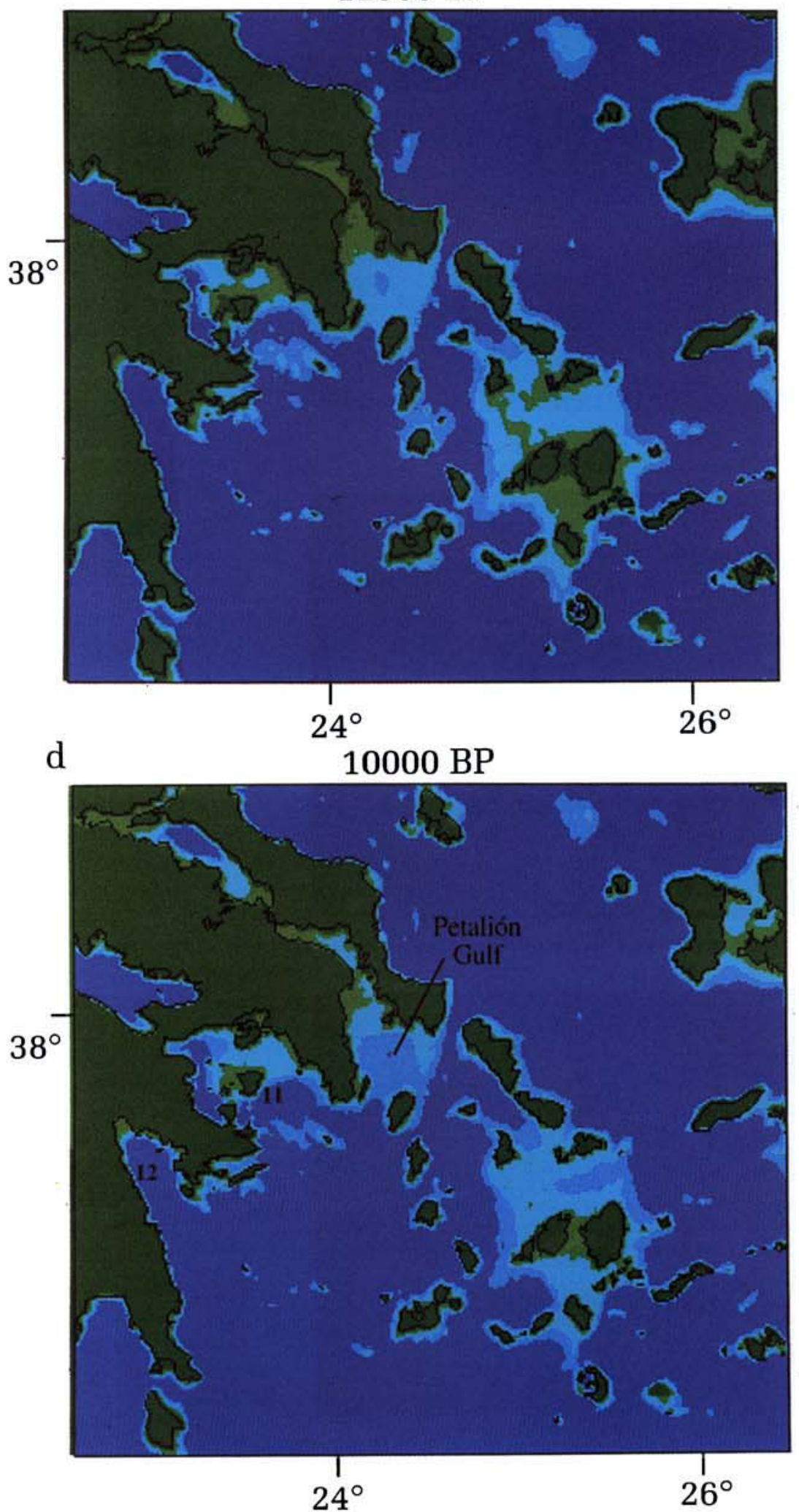

FIGURE 6.

Palaeogeographic reconstructions for the Aegean region at four epochs. The water-depth contours are drawn at 50 and $100 \mathrm{~m}$, and the land contour is for $50 \mathrm{~m}$ only.

1 Kéa

2 Kithnos

3 Sérifos

4 Sifnos

5 Milos

6 Andros

7 Tinos

8 Páros

9 Amorgós

10 Thira

11 Saronikós Gulf

12 Argolis Gulf

Other place names are located in FIGURES 7 88. 


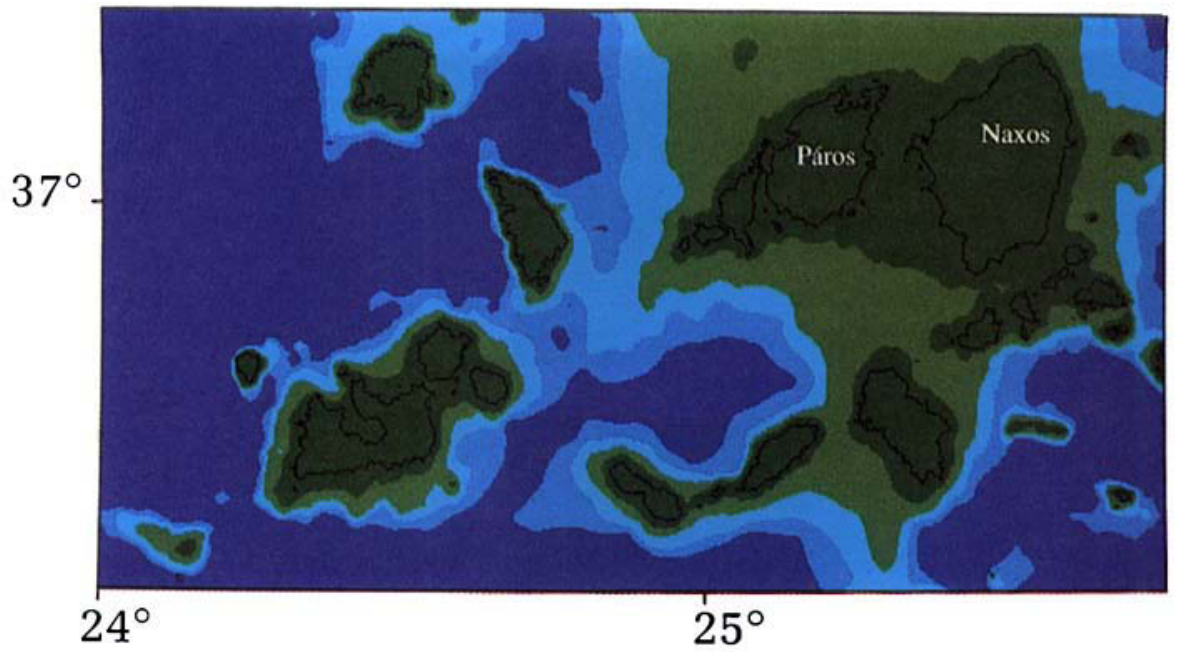

a
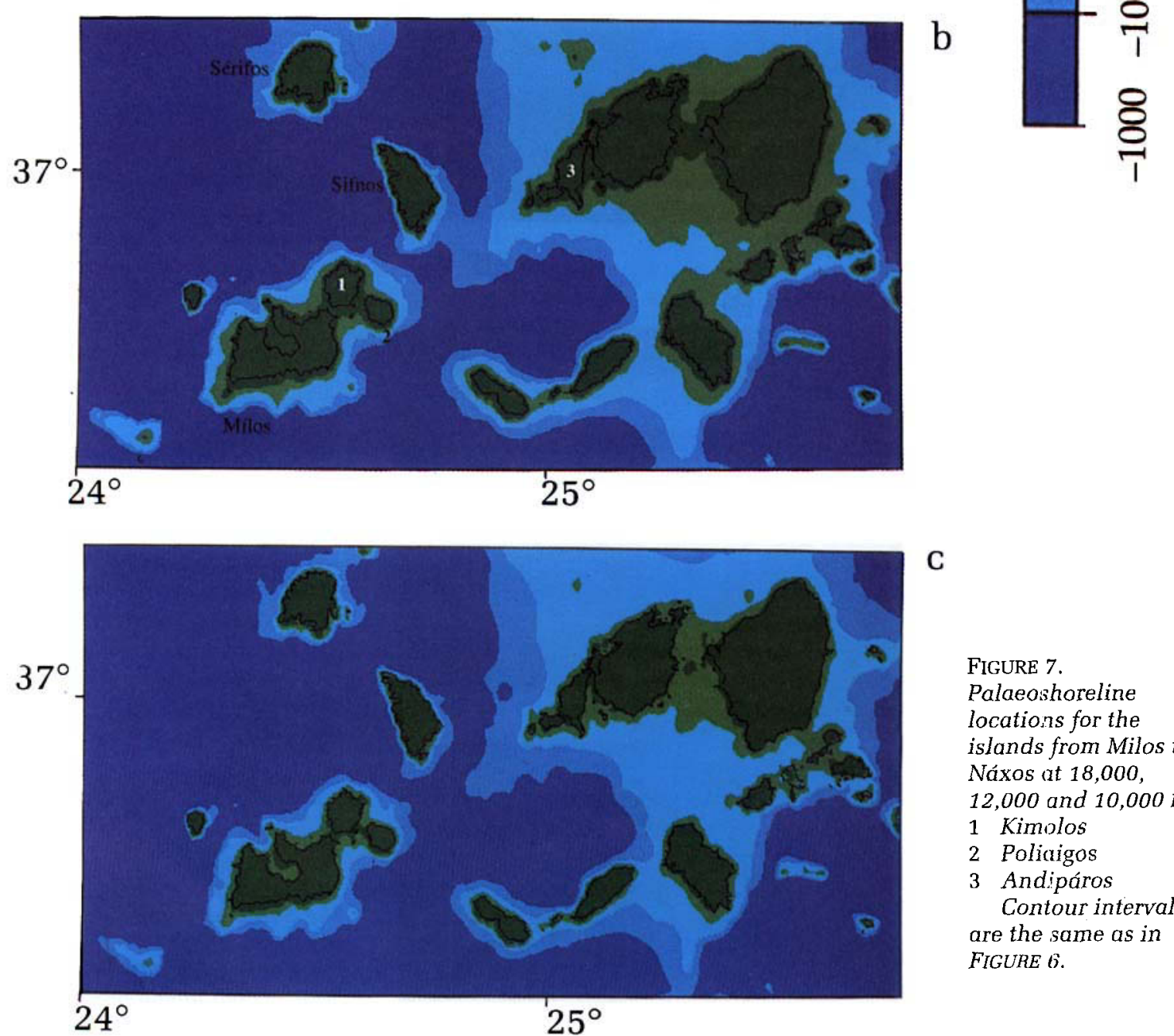

C

FIGURE 7.

Palaeoshoreline locations for the islands from Milos to Náxos at 18,000, 12,000 and $10,000 \mathrm{BP}$. 1 Kimolos

2 Poliaigos

3 Andipáros Contour intervals are the same as in FIGURE 6. 


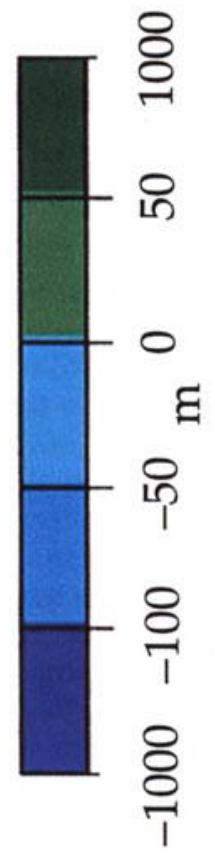

a

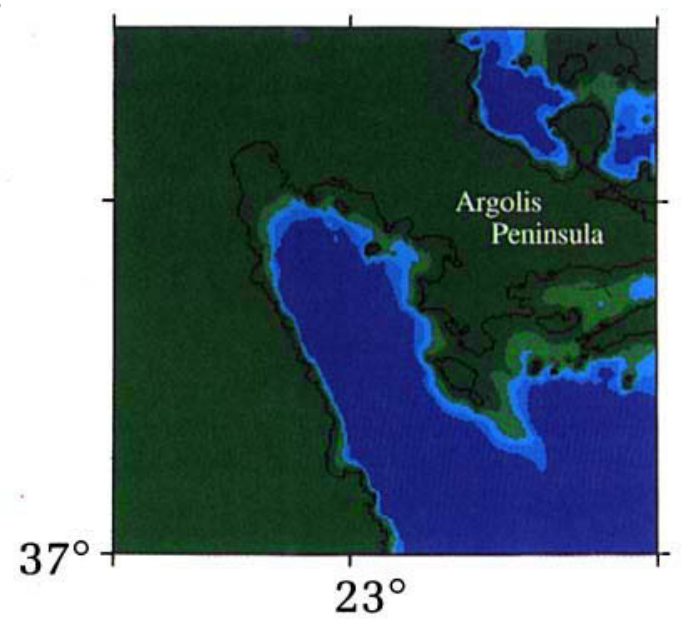

$\mathrm{b}$

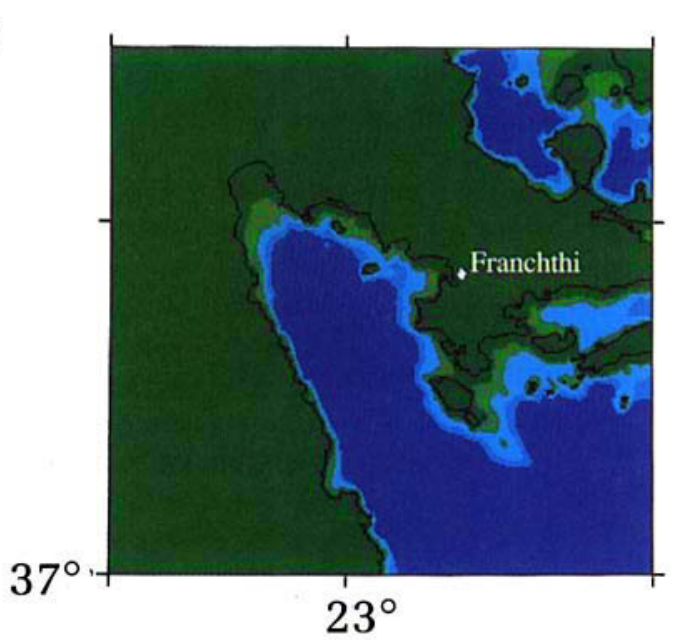

FIGURE 8. Palaeoshorelines around the Argolis Peninsula and the Gulf of Argos at 18,000, 12,000 and $10,000 \mathrm{BP}$.

Contour intervals are the same as in FIGURE 6.

C

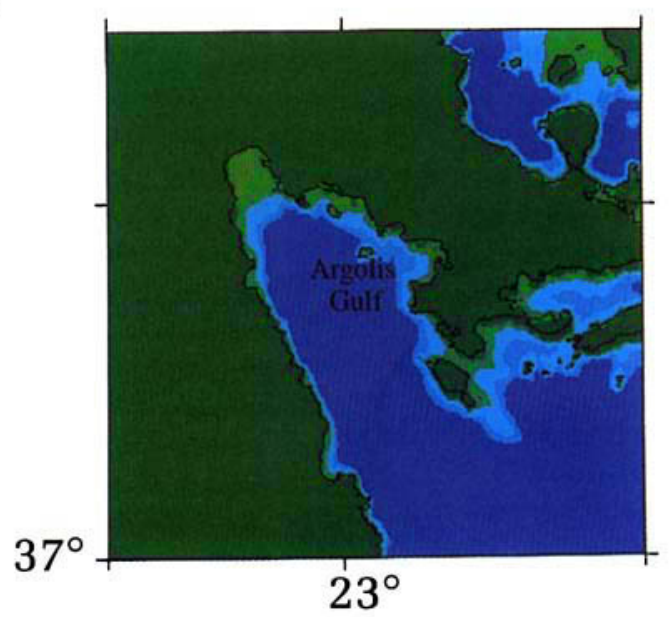


that 4000 years earlier (FIGURE $6 \mathrm{~b}$ ) although some of the narrow channels separating the various island groups have expanded marginally. After about 14,000 b.p. the sea-level rise is more rapid. The Cycladean Island begins to break up into northern and southern parts that are separated by shallow sea, break-up being completed soon after 12,500 b.p. At this time the Milos group is separated from the southern Cycladean island, via Sifnos, by a minimum water crossing of about $14 \mathrm{~km}$. By 12,000 b.p. the two main parts of the earlier Cycladean Island are separated by a minimum distance of about $17 \mathrm{~km}$. At 10,000 b.p. the original Cycladean Island has broken up further, and the geography of the region is beginning to resemble the present configuration. The southern part of the Evvöikós Gulf is first subjected to marine influence at about 9000 b.p. and the northern sector, through the Dhiavlos Strait, before 8000 b.p. The islands of Milos, Kimolos and Poliaigos remain together with decreasing surface area until about 8500 b.p. The final separation of Náxos, Páros and Andipáros also occurs at about this time. Likewise, the area of the coastal plains around the periphery of the present Argolis Peninsula is gradually reduced throughout this period (FIGURE 8).

\section{Shorelines from Late Neolithic time to the present}

During Late Neolithic and Bronze Age times (after about 6000 years b.p.), the predicted change is a sea-level rising at a rate of about 0.7-1.0 mm per year, small compared with that for the earlier period when the rates were as high as $12 \mathrm{~mm} /$ year (FIGURE 4). The Late Holocene rates are comparable to the vertical tectonic rates inferred for some localities in the region, an effective separation of the two contributions to relative sea-level change is now more problematical. For example, the local modification of shorelines by sedimentation may now become important in areas such as the upper reaches of the Argolis Gulf. Nevertheless, the characteristic regional pattern is a slow encroachment of the sea throughout this period, consistent with observations of Bronze Age and more recent sites that are now a few metres below sea-level in, for example, Milos (Bintliff 1976), Andipáros (Morrison 1968) and near the Franchthi Palaeolithic cave site (Jacobsen \& Farrand 1987). If local bathymetric maps are avail- able, the shoreline evolution for this period is best estimated by superpositioning upon them the sea-level predictions given in FIGURE 4.

Early Palaeolithic to Early Upper Palaeolithic shorelines

FIGURE 3 illustrates the predicted sea-level oscillations for Páros near the centre of the present Cycladean island group from the time of the penultimate Glacial Maximum (Saalian) at about 140,000 years ago to the present. Spatial variability of sea-level occuring across the region will generally be small when compared with the larger uncertainties introduced by incomplete knowledge of the ice sheets before about 20,000 years b.p. As the Last Glacial Maximum appears to have been of relatively short duration, the coastal plains were fully exposed from only a little before 20,000 years b.p. to about 16,000 years b.p. The maximum development of the Cycladean Island would therefore have been restricted to between about 21,000 and 14,000 years b.p. The only other time in the last 150,000 years that these low levels would have been reached is during the penultimate Glacial Maximum before about 135,000 years b.p. From about 70,000 years b.p. to the lead-up to the Last Glacial Maximum, sea-levels oscillated between about -50 and $-80 \mathrm{~m}$ and shoreline locations would have been similar to those that occurred later between about 12,000 and 10,000 years b.p. (FIGURE 6). Between about 110,000 and 70,000 years b.p. the water depths and shorelines are characteristic of conditions last experienced between about 9000 and 7000 years b.p.

\section{Limitations of the shoreline reconstructions} The reconstructions of past topography and shoreline locations are model dependent, notably on the assumed eustatic sea-level function, on the appropriate earth-model parameters that define the isostatic contributions, and on the assumed absence of other tectonic and sedimentary processes. Constraints on the model parameters are provided by observations of past sea-levels, and the practice is first to calibrate the eustatic and isostatic models with data from stable regions and then to apply them to the tectonically active areas. Solutions of the sealevel equation (4) have therefore tended to be iterative: observations of sea-level change from both the area of interest and from areas outside of it are compared with the model predic- 
tions to improve the estimates of the parameters that define both the isostatic model and the tectonic components. Predictions for the Aegean point to potential tests to check the correct timing of the shoreline movements. For example, the model predicts that the Saronikós Gulf was separated from the Aegean Sea and from marine influence between about 23,000 and 13,000 years ago and sedimentary cores from the central areas of the depression may contain information on the timing of the first marine transgression and - through the sealevel equation - on the eustatic sea-level function. Other potential target areas for testing the model are the Petalión Gulf, or possibly the nowshallow sea floor depression between Náxos and Mikonos (FIGURE 6).

As noted above, resolution of the digitized and gridded nautical charts gives a spatial resolution of about $2 \mathrm{~km}$, so some very fine detail is lost in the reconstructions. FIGURE 8c, for example, shows Idrha connected to the mainland at about 10,000 b.p., whereas there would actually have been a narrow channel - less than about $500 \mathrm{~m}$ wide - between the two. Similar resolution is lost between those islands of the Cycladean group that are separated by very narrow and deep channels.

The model predictions, most reliable for the time since the Last Glacial Maximum, are also indicative of conditions throughout Early and Mid Palaeolithic time. Thus the reconstruction in FIGURE 6 for the interval 12,500-14,000 years b.p. also represents conditions between about 25,000-22,000 years b.p. Some question does remain about the time-scale appropriate to observation and prediction. All ages here refer to the conventional radiocarbon time-scale since most observations of sea-level change and of the retreat of ice sheets use radiocarbon determinations. Insofar as archaeological determinations for Palaeolithic and Neolithic contexts also refer to this time-scale, the models are consistent with those data. Care is required when using calendar ages for the more recent times because discrepancies between this and the radiocarbon time-scale can be substantial (e.g. Klein et al. 1982; Bard et al. 1990).

\section{Shorelines and the human environment}

The examples set out here indicate that reconstructions of the contemporaneous geography should be integral to discussion of early coastal inhabitants of Greece. With some notable exceptions, the full recognition of this input has been neglected. That sea-levels during the Last Glacial Maximum were some 100-150 m lower than today is not a matter for dispute in the archaeological and prehistory literature. Nor is the fact that at that time extensive coastal plains would have been exposed, plains that would generally have seen much human activity (e.g. Gamble 1986). Less attention has been paid to the timing of the sea-level rise from then up to about 6000 years ago, and to the fact that this rise occurred over a substantial time interval. Van Andel \& Shackleton (1982) and van Andel (1989), in neglected papers, attempted to quantify sea-level and shoreline changes in the eastern Mediterranean during this Late Glacial period and recognized that the rise occurred over an extended period, with important human implications as the progressive reduction of the relatively hospitable coastal plain environment caused a concomitant loss of resources. The consequences would have been particularly severe for the Cycladean Island, where an extensive, relatively flat and low-lying plain was progressively reduced to a few rocky islands over a period of about 6000 years (FIGURE 6). Likewise, the coastal plains of the palaeo Argolis Peninsula (FIGURE 8) could have offered a hospitable environment for Palaeolithic and Neolithic dwellers. Certainly throughout the Aegean region, these now-flooded plains are likely to have been more conducive to human activities than much of the present coastal zone and human traffic patterns and migration routes may well have been quite different in the past. Can this, for example, explain the general paucity of evidence for Palaeolithic occupation of the region. Did the encroaching sea cover much of the evidence for the activities of early people until about 10,000-9000 years b.p.? Even in Early Bronze Age times, sea-levels were lower than today by as much as $5 \mathrm{~m}$ and, as the region has been a zone of low tidal range throughout, much of the archaeological evidence for this interval may also be below today's sea-level.

Locally, the coastal changes may have been significant. In Milos the coastal plain was considerably more extensive at the time when obsidian from this island first appears on the mainland in latest Palaeolithic time (FIGURE 7). Can this explain the apparent absence of Late Palaeolithic and Early Neolithic settlement on 

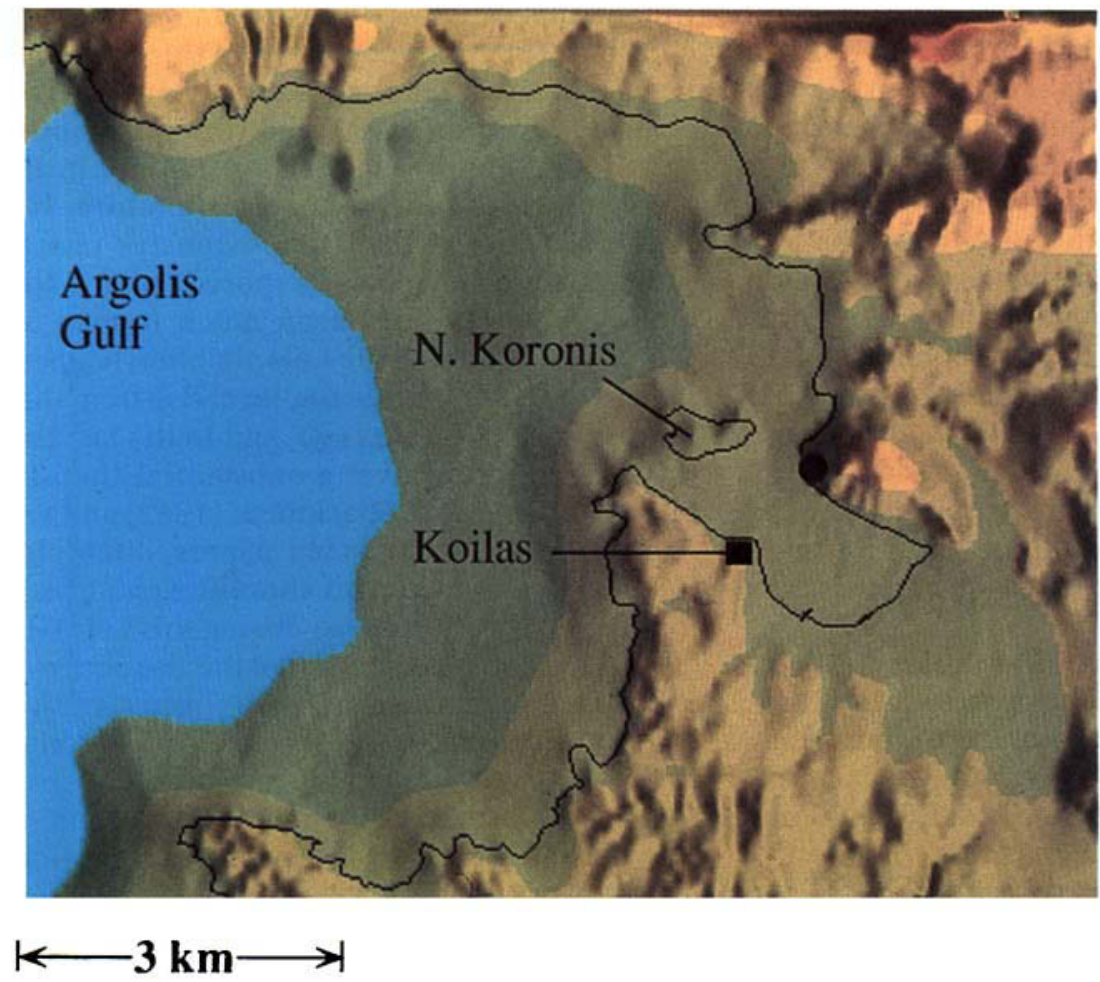

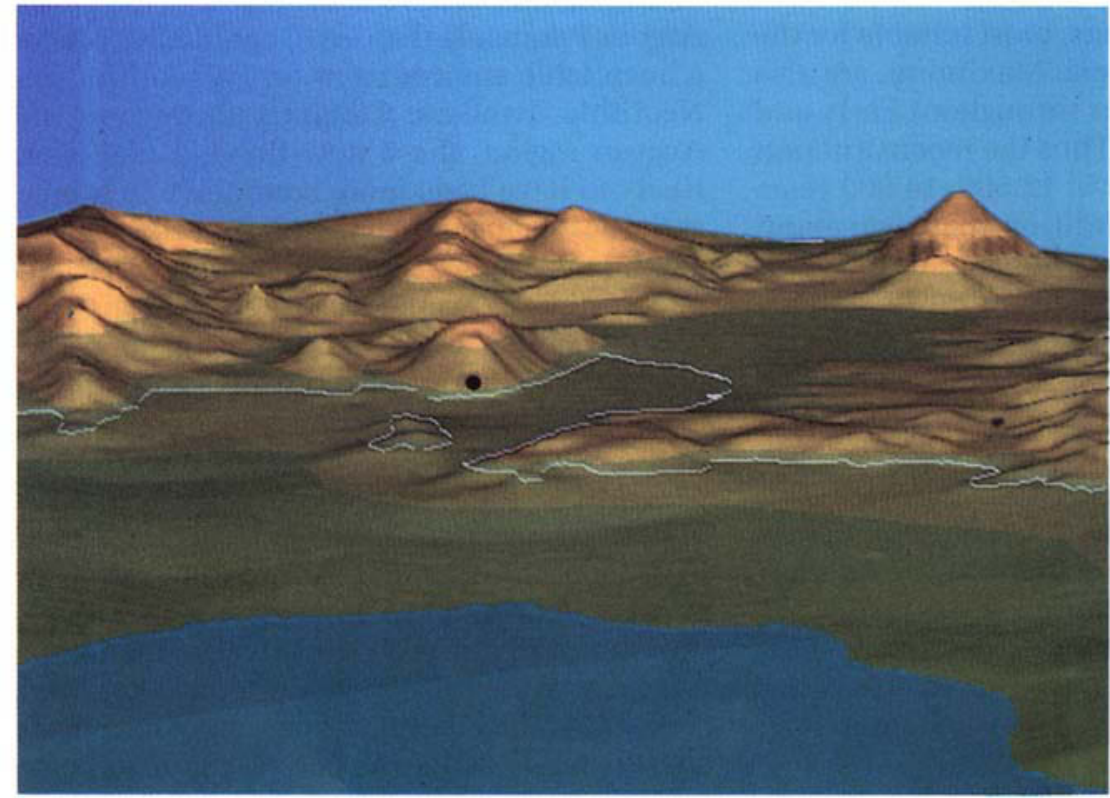

12,000 b.p. $\mathrm{b}$

FIGURE 9. Coastal configuration in the Argolis Gulf near the Palaeclithic site of Franchthi at 12,000 and $8000 \mathrm{BP}$. The perspective views are from a point to the west of the cave site which is marked by the solid circle. The square locates the present town of Koilás. 
$\mathrm{C}$

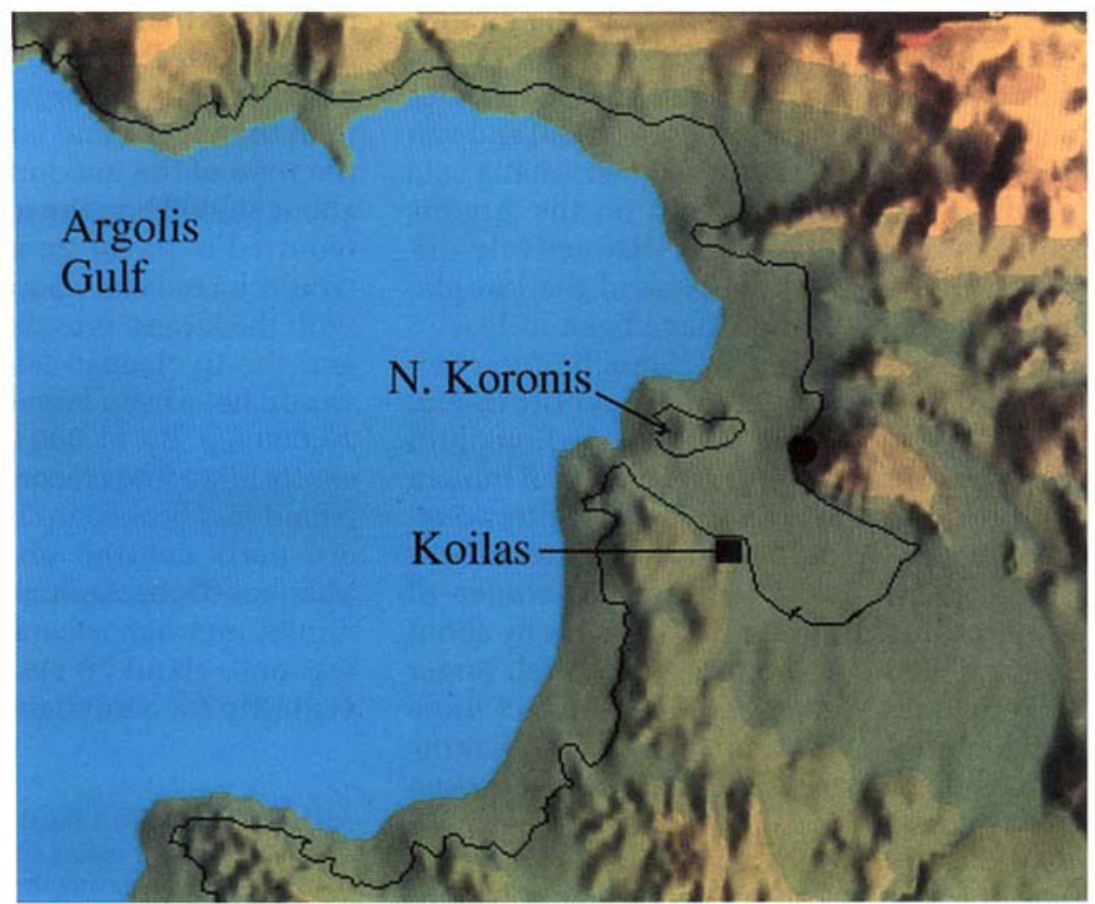

$-3 \mathrm{~km}$

d

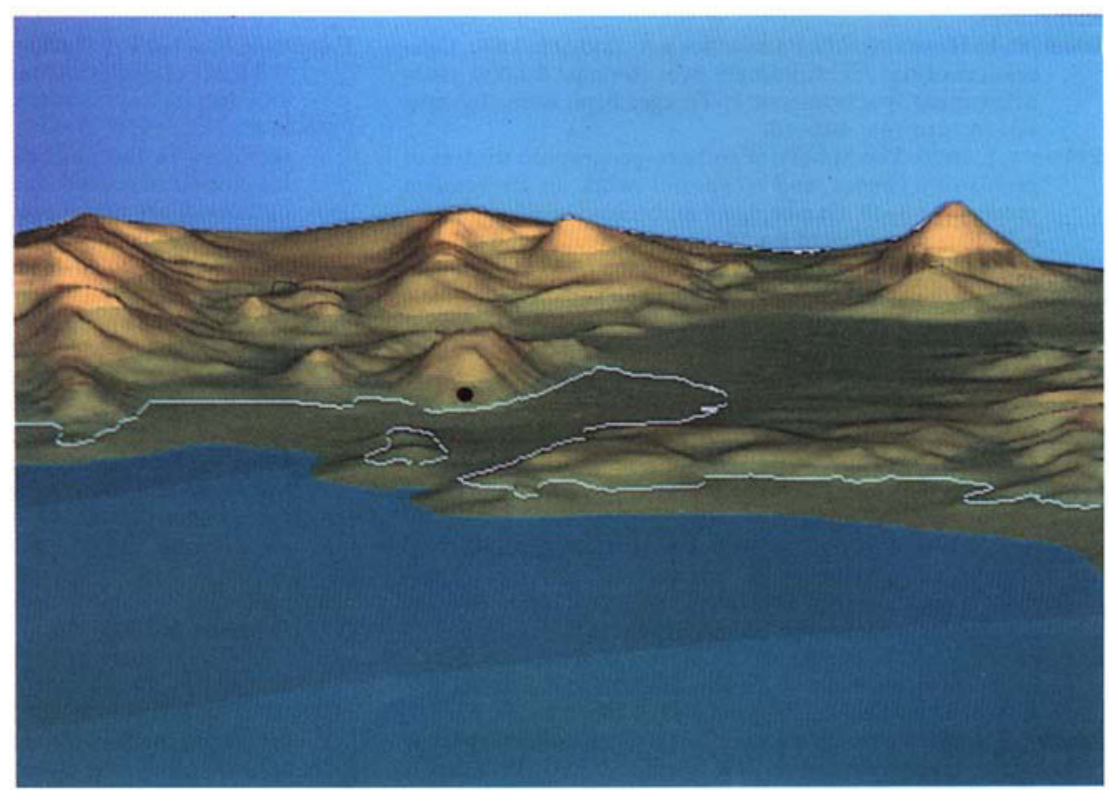

8,000 b.p. 
the island (Renfrew 1972) despite the quarrying that must have occurred to obtain the obsidian found on the mainland? Likewise - as already emphasized by Jacobsen (1969) and van Andel (1987) - the coastal geometry at the Late Palaeolithic site at Franchthi on the Argolis Peninsula, would have been distinctively different in the past. At the peak of the last glaciation, the coast would have been at least 6 $\mathrm{km}$ to the west (FIGURE 9); if much of the evidence for the activities of Palaeolithic and Neolithic people is now submerged, Franchthi Cave represents only a partial record of human activity in the area. Certainly any interpretation of the cave record needs to consider these shifting shorelines. Does the appearance of marine molluscs and small fish bones by about 12,000-10,000 b.p., and the first much larger fish vertebrae by about 9200 b.p. reflect more on the coastal evolution than on the fishing methods of the early inhabitants, as Jacobsen (1976) suggested?

Obsidian from Milos appears in the Franchthi strata after about 11,000 b.p. (Perlès 1987; Renfrew \& Aspinall 1987) (Perlès (1979) and Cherry $\&$ Torrence (1982), quoting Perlès, give an age

\section{References}

BARD, E., B. HAMELIN, R.G. FAIRBANKS \& A. ZINDLER, 1990. Calibration of the ${ }^{14} \mathrm{C}$ timescale over the past 30,000 years using mass spectrometric U-Th ages from Barbados corals, Nature 345: 405-10.

BINTLIFF, J. 1976. The history of archaeo-geographic studies of prehistoric Greece, and recent fieldwork, in Mycenaean geography: 3-16. Cambridge: Cambridge University Press \& British Association for Mycenaean Studies.

CATHLES, L.M. 1975. The viscosity of the Earth's mantle. Princeton (NJ): Princeton University Press.

ChAPPEL. , $_{3}$ J. 1983. Evidence for a smoothly falling sea-level relative to north Queensland, Australia, during the past 6000 years, Nature 302: 406-8.

Chappell, J. \& H. POllach. 1991. Post-glacial sea-level rise from a coral record at Huon Peninsula, Papua New Guinea, Nature 349: 147-9.

ChAPPELl, J. \& N.J. ShaCKLETON. 1986. Oxygen isotopes and sea-level, Nature 324: 137-40.

ChERRY, J.F. \& R. TORRENCE. 1982. The earliest prehistory of Melos, in C. Renfrew \& M. Wagstaff (ed.), An island polity: the archaeology and exploitation in Melos: 24-34. Cambridge: Cambridge University Press.

COLLIER, R.E.L., M.R. LEEDER, P.J. ROWE \& T.C. ATKINSON. 1992. Rates of tectonic uplift in the Corinth and Megara Basins, Central Greece, Tectonics 11: 1159-67.

CURRAY, J.R. 1965. Late Quaternary history, continental shelves of the United States, in H.E. Wright \& D.G. Frey (ed.), The Quaternary of the United States: 723-35. Princeton (NJ): Princeton University Press.

DENTON, G.H. \& T.]. HuGHEs (ed.). 1981. The last great ice sheets. New York (NY): Wiley. of 11 th millennium b.c.). With the lower sealevels of Late Palaeolithic time, the island would have been much more accessible from the mainland than it became later as sea-levels rose. At the time of the maximum gliaciation and until about 16,000 b.p. the minimum water crossing required to travel from Milos to the mainland would have been about $8 \mathrm{~km}$ (FIGURES 6 \& 7), with the largest crossing being between Sifnos and the Cycladean Island; this configuration would have been largely preserved until about 13,000 b.p. By 11,000 b.p., the time of the oldest obsidian finds recorded so far, the Cycladean Island had broken up into northern and southern parts centred on Páros-Andipáros and Mikonos-Tinos-Andros although at this time the minimum water separation across shallow seas was only about $20 \mathrm{~km}$, with clear inter-island visibility for a daylight crossing.

Acknowledgements. I thank Dr C.L. Smither and Mrs C. Krayshek for their major effort in digitizing the nautical charts and for preparing the figures. I thank Professor G. Veis and Dr Lysandros Tsoulos of the National Technical University of Athens for making available the non-marine topographic data.

FAIRBANKS, R.G. 1989. A 17,000-year glacio-fustatic sea-level record: influence of glacial melting dates on the Younger Dryas event and deep ocean circulation, Nature 342: 637-42.

FLEMMING, N.C. 1978. Holocene eustatic changes and coastal tectonics in the northeast Mediterranean: implications for models of crustal consumption, Philosophical Transactions of the Royal Society of London A289: 405-58.

GAMBLE, C. 1986. The Palaeolithic settlement of Europe. Cam bridge: Cambridge University Press.

HMGS = HelieniC Military GeOGRAPHICAL SERviCE. 1992. 1:50,000 map sheet Spetsai. Athen.s.

HNHS = HELLENIC NAVY HYDROGRAPHIC SERVICE. 1993. 1:100,000 Nautical Charts $412-414$ and 150,00u Nautical Charts 415, 421, 423. Athens.

HYVÄRINEN, H. 1980. Relative sea-level changes near Helsinki, southern Finland, during early Litorina time, Bulletin of the Geological Society of Finland 52: 207-19.

JACKSON, J. 1994. Active tectonics of the Aegean region, Annual Review of Earth and Planetary Science 22: 239-71.

JACOBSEN, T.W. 1969. Excavations at Porto Cheli and vicinity, preliminary Report, II: 'The Franchthi Cave, 1967-1968, Hesperia 38 : 343-81.

1976. 17,000 years of Greek prehistory, Scientific American 234(6): 76-87.

JACOBSEN, T.W. \& W.R. FARRAN. 1987. Franch thi Cave and Paralia. Bloomington (IN): Indiana University Press. Excavations at Franchthi Cave, Greece Fascicle 1.

KELLETAT, D., G. KOWALGZYK, B. SCHRÖDER \& K.P. WINTER. 1976. A synoptic view on the neotectonic development of the Peloponnesian coastal regions, Zeitsichrift der Deutsche Geologische Gesellschaft 27: 447-65. 
KERAUDREN, B. \& D. SOREL. 1987. The terraces of Corinth (Greece) - a detailed record of eustatic sea-level variations during the last 500,000 years. Marine Geology 77: 99-107.

KLEIN, J., J.C. LERMAN, P.E. DAMON \& E.K. RALPH, 1982, Calibration of radiocarbon dates, Radiocarbon 24: 103-50.

KRAPT, J.C., S.E. AsChENBRENNER \& G.J. RAPP. 1977. Paleogeographic reconstructions of coastal Aegean archaeological sites, Science 195: 941-47.

KRAFT, J.C. \& G.J. RAPP. 1975. Late Holocene paleogeography of the coastal plain of the Gulf of Messenia, Greece, and its relationships to archaeological settings and coastal change, Geological Society of America Bulletin 86: 11911208.

KRAFT, J.C., G.R. RAPP \& S.E. A.SCHENBRENNER. 1980. Late Holocene palaeogeomorphic reconstructions in the area of the Bay of Navarino: Sandy Pylos, Journal of Archaeological Science 7: 187-210.

LAMBECK, K. 1988. Geophysical geodesy: the slow deformations of the earth. Oxford: Oxford University Press.

1993. Glacial rebound of the British Isles II: A high resolution, high-precision model, Geophysical Journal International 115: 960-90

1995a. Late Pleistocene and Holocene sea-level change in Greece and southwestern Turkey; a separation of eustatic, isostatic and tectonic contributions, Geophysical journal International 122: 1022-44.

1995b. Constraints on the Late Weichselian ice sheet over the Barents Sea from observations of raised shorelines, Quaternary Science Review 14: 1-16.

In press. Sea-level change along the French Atlantic coast since the time of the Lastglacial Maximum, Palaeogeography, Palaeoclimatology, Palaeoecology.

LAMBECK, K., P. JOHNSTON \& M. NAKADA. 1990. Holocene glacial rebound and sea-level change in NW Europe, Geophysical Journal International 103: 451-68.

LAMBECK, K., P. JOHNSTON, C. SMITHER \& M. NAKAdA. 1996. Glacial rebound of the British Isles III: Constraints on mantle viscosity, Geophysical Journal International 125: $340-54$.

LAMBECK, K. \& M. NAKADA. 1990. Late Pleistocene and Holocene sea-level change along the Australian coast, Palaeogeography, Palaeoclimatology, Palaeoecology (Global and Planetary Change Section) 89: 143-76.

Milliman, J.D. \& K.O. EMERY. 1968. Sea-levels during the past 35,000 vears, Science 162: 1121-3.

Mrtrovica, J.X. \& W.R. PElTER. 1991. On postglacial geoid subsidence over the equatorial oceans, Journal of Geophysical Research 96: 20,053-71.

1993. The inference of mantle viscosity from an inversion of the Fennoscandian relaxation spectrum, Geophysical Journal International 114: 45-62.

MORRISON, I.A. 1968. Appendix I. Relative sea-level change in the Saliagos area since Neolithic times, in J.D. Evans \& C. Renfrew (ed.), Excavations at Saliagos near Antiparos: 92-8. London: Thames \& Hudson.
NAKADA, M. \& K. LAMBECK. 1987. Glacial rebound and relative sea-level variations: a new appraisal, Geophysical journal of the Royal Astronomical Society 90: 171-224.

NAKADA, M. \& K. LAMBECK. 1988. The melting history of the Late Pleistocene Antarctic ice sheet, Nature 333: 36-40.

PELTIER, W.R. \& J.T. ANDREWS. 1976. Glacial-isostatic adjustment - 1. The forward problem, Geophysical Journal of the Royal Astronomical Society 46: 605-46.

PERLÈs, C. 1979. Des navigateurs méditerranéens il y a 10,000 ans, La Recherche 10: 82-3.

1987a. Les industries lithiques taillés de Franchthi (Argolide, Grècel, in Perlès (ed.): 142-3.

(Ed.). 1987b. Présentation générale et industries paléolithiques. Bloomington (IN): Indiana University Press. Excavations at Franchthi Cave, Greece Fascicle 3(1).

PIRAZZOLI, P.A., S.C. STIROS, M. ARNOLD, J. LABOREL, F. LABORELDEGUEN \& S. PAPAGEORGIOU. 1994. Episodic uplift deduced from Holocene shorelines in the Perachora Peninsula, Corinth area, Greece, Tectonophysics 229: 201-9.

RENFREW, C. 1972. The emergence of civilisation: the Cyclades and the Aegean in the 3rd millennium BC. London: Methuen.

RENFREW, C. \& A. ASPINALL. 1987. Aegean obsidian and Franchthi Cave, in Perlès (ed): 257-70.

SAMBRIDGE, M., J. BRAUN \& H. MCQUEEN. 1995. Geophysical parametrization and interpolation of irregular data using natural neighbours, Geophysical Journal International 122: 837-57.

SHACKLETON, N.J. 1987. Oxygen isotopes, ice volume and sealevel, Quaternary Science Review 6: 183-90.

ThOMMERET, Y., J. LABOREL, L.F. MONTAGGIONI \& P.A. PIRAZZOLI. 1981. Late Holocene shoreline changes and seismo-tectonic displacements in western Crete (Greece), Zeitschrift für Geomorphologie (neue Folge) 40:127-49.

Tushingha., A.M. \& W.R. Peltier. 1991. Ice 3G: a new global model of Late Pleistocene deglaciation based upon geophysical predictions of postglacial sea-level change, Journal of Geophysical Research 96: 4497-523.

VAN ANDEL, T.H. 1987. The adjacent sea, in T.H. van Andel \& S.B. Sutton (ed.), Landscapes and people of the Franchthi region: 3-64. Bloomington (IN): Indiana University Press. Excavations at Franchthi Cave, Greece Fascicle 2.

VAN ANDEL, T.H. 1989. Late Quaternary sea-level changes and archaeology, Antiquity 63: 733-46.

VAN ANDEL, T.H. \& N. Lianos. 1983. Prehistoric and historic. shorelines of the southern Argolid Peninsula: a subbottom profiler study, Nautical Archaeology 12(4): 303-24.

VAN ANDEL, T.H. \& J.C. SHACKLETON. 1982. Late Paleolithic and Mesolithic coastlines of Greece and the Aegean, Journal of Field Archaeology 9: 445--54.

ZWARTZ, D., K. LAMBECK, M. BIRD \& J. STONE. IN PREPARATION. Constraints on the former Antarctic ice sheet from sealevel observations and geodynamic modelling, in Proceedings of the VII International Symposium on Antarctic Earth Sciences, Siena, Italy. 